\title{
On the Economics and Politics of Refugee Migration*
}

\author{
Christian Dustmann**, Francesco Fasani***, Tommaso Frattini ${ }^{\circ}$, Luigi Minale ${ }^{\circ \circ}$, \\ and Uta Schönberg ${ }^{\circ \circ \circ}$
}

February 2017

\begin{abstract}
This paper provides a comprehensive analysis of refugee migration, with emphasis on the current refugee crisis. After first reviewing the institutional framework laid out by the Geneva Convention for Refugees, we demonstrate that, despite numerous attempts at developing a common European asylum policy, EU countries continue to differ widely in interpretation and implementation. We then describe key features of the current refugee crisis and document the overall magnitudes and types of refugee movements, illegal border crossings, and asylum applications to EU member states. We next study the labour market integration of past refugee migrants to EU countries and draw conclusions for the current situation. Finally, we turn to the economics of refugee migrations, contrasting economic and refugee migrants, discussing the tradeoffs between long-term asylum and temporary protection, and highlighting the benefits of wellcoordinated national asylum policies. We conclude with several policy recommendations.
\end{abstract}

JEL Codes: F22, J15, J61

Keywords: asylum policy, asylum seekers, refugee crisis

\footnotetext{
* Luigi Minale gratefully acknowledges support from the Ministerio de Economía y Competitividad (Spain, Maria de Maeztu Grant) and Comunidad de Madrid (MadEco-CM S2015/HUM-3444). Christian Dustmann acknowledges funding through the Norface WSF Programme and the DFG (DU1024/1-1).

This paper has been prepared for presentation at the 64th Panel Meeting of Economic Policy in October 2016.

** UCL and CReAM

*** QMUL, CReAM and CEPR

${ }^{\circ}$ University of Milan, LdA and CReAM

${ }^{\circ}$ Universidad Carlos III de Madrid, CReAM and IZA

${ }^{\circ} \mathrm{O}$ UCL, CReAM, and IAB
} 


\section{Introduction}

For the first time since the large refugee movements of the 1990s, which followed the breakup of the bipolar order that had dominated Europe since the 1950s, a refugee crisis tops European policy debate. The earlier crisis resulted from the political restructuring of South-Eastern Europe after the Balkan wars and the dissolution of Yugoslavia, which had displaced about 2,700,000 people by the end of 1995, over 700,000 of whom sought asylum in European Union (EU) member states (see UNHCR, 2000). The current movements are due primarily to the events that followed the 2001 bombings of New York's twin towers and the uprising in the Middle East commonly known as the "Arab Spring". In 2015 alone, Europe received a total of 1.5 million asylum applications, an unprecedented high that is almost double the previous 1992 peak of 850,000.

At least three features distinguish the present refugee crisis from that in the early 1990s: First, the refugee movements of the early 1990s happened in the aftermath of decades of cold war, a dark era from which an optimistic Europe emerged eager to embrace new economic opportunities and European integration and enlargement. The current crisis, in contrast, falls upon an enlarged Europe, still entangled in the aftershocks of a deep recession, riddled by populist and separatist national movements, and challenged by deeply divergent views about how to address this humanitarian crisis. Second, whereas the Balkan wars were considered mainly a Western responsibility, and Western resolve finally helped to restore stability, the current crisis involves a multitude of actors and geo-political interests over which Western nations have limited power. And third, the refugees who are currently heading towards Europe are perceived to be culturally more distinct and greater in number than those in the early 1990 s.

As a result of these differences, the current crisis is characterized by at least three political challenges: First, and most important, European nations can only marginally influence the primary 
causes of the conflicts inducing current refugee flows. There is thus no clear indication of when such flows might abate, and no clear time frame for when those who have fled the conflict can be resettled, if at all. Such a lack of predictability creates uncertainty and concern among the populations in the receiving countries, whose fears are easily exploitable by populist movements. Second, the dire economic situations in which many European countries find themselves, coupled with the different views about humanitarian responsibilities, impede political progress and solutions. Lastly, the lack of a clear legal framework; the unsuitability of past regulations, which have led to confusing ad-hoc exceptions; the differences in implementation and interpretation of the underlying Geneva Convention for Refugees across European countries; and the challenges that the current crisis poses for the Schengen Agreement have led to a situation in which political progress is proving extremely difficult.

In this paper, we provide background and shed new light on the complexities of the refugee crisis Europe faces. We first answer the question "who is a refugee?" (section 2). We start from the definition laid out in the 1951 Geneva Convention for Refugees (GCR) and emphasize the tremendous heterogeneity in how different European countries interpret and implement it. We argue that this diversity in GCR interpretation and implementation is one important reason for the current lack of political progress that we are witnessing. We then identify the major source areas of the current crisis and resulting migrations (section 3) by documenting the sharp increases in asylum applications to EU member states from 2009 onwards, and its unequal distribution across EU member states.

In section 4, we use data from the 2008 wave of the EU Labour Force Survey to profile the economic integration of past refugee migrants to EU countries. In particular, we show that migrants who arrived for humanitarian reasons were less likely to be employed than economic 
migrants from the same origin areas despite similar levels of education. This evidence from past refugee movements underscores the particular challenges to host countries and indicates the need for more proactive policies to prevent the poor economic outcomes of refugees.

We then examine the economics of refugee migrations by first contrasting refugee migration with economic migration (section 5). We argue that whereas the latter is a choice for all parties involved, refugee migrants are forced to leave their home country because of threats to their own lives or those of their family, and countries that receive refugees do so for humanitarian not economic reasons. Further, host countries tend not to have economic integration of the refugee migrants as their primary objective. Receiving countries can decide whether to reject asylum claims, grant full GCR refugee status (which often leads to permanent settlement in the host country), or offer temporary forms of humanitarian support. These different options, by creating different degrees of permanence for individual refugees, greatly affect their incentives to integrate socially and contribute economically. We suggest that clear rules and support mechanisms are needed early on in the migration history, together with fast processing times, fast access to the labour market, and active integration programs. We conclude section 5 by highlighting the economic advantages of increased coordination in the asylum process across countries; for instance, at the EU level. Such increased coordination would reduce the free-rider problem inherent in the provision of (the public good of) refugee status, minimize the costs of providing asylum to a given number of refugees, and alleviate countries' incentives to implement policies aimed at deterring asylum applications, which may harm refugee integration.

We finally discuss the implications of earlier evidence for optimal and feasible refugee policies that Europe should implement not simply to address the current crisis but also to deal with future migration developments. 


\section{Who is a refugee?}

\subsection{The international framework}

Modern refugee legislation has its origins in the aftermath of World War II and in the refugee crises of the preceding interwar years. Grounded in Article 14 of the 1948 Universal Declaration of Human Rights, which recognizes the right of persons to seek asylum from persecution in other countries, the United Nations Geneva Convention relating to the Status of Refugees (GCR) was adopted in 1951. In its first article, the convention defines the refugee as follows:

[any person who] owing to a well-founded fear of being persecuted for reasons of race, religion, nationality, membership of a particular social group or political opinion, is outside the country of his nationality and is unable or, owing to such fear, is unwilling to avail himself of the protection of that country; or who, not having a nationality and being outside the country of his former habitual residence as a result of such events, is unable or, owing to such fear, is unwilling to return to it.

The GCR not only broadly defines the rights of refugees and the obligations of hosting states but establishes the principle of non-refoulement (article 33), which prevents host countries from returning refugees against their will to any territory in which they fear a threat to life or freedom ${ }^{1}$. Although the convention was originally limited to persons fleeing events occurring within Europe and before January 1, 1951, the 1967 Protocol removed these limitations and endowed the GCR with universal coverage. As of April 2015, 145 states have signed the 1951 Convention and 142 have signed both the Convention and the 1967 Protocol.

Being the only global legal instruments that explicitly regulate refugee rights, the 1951 Convention and the 1967 Protocol still define the international framework regulating asylum policy.

\footnotetext{
1 "No Contracting State shall expel or return ("refouler") a refugee in any manner whatsoever to the frontiers of territories where his life or freedom would be threatened on account of his race, religion, nationality, membership of a particular social group or political opinion" (Geneva Convention, article 33.1).
} 
Nevertheless, being based on the concept of individual persecution, the GCR definition of refugees does not specifically address the more general issue of civilians fleeing wars and conflicts. The United Nations High Commissioner for Refugees (UNHCR), however, considers that persons fleeing the civil wars and ethnic, tribal, and religious violence and whose country of origin is unwilling or unable to protect them should be considered refugees even if they are fleeing a general rather than an individual threat. Hence, some regional human rights treaties have since expanded the GRC definition to include these people. ${ }^{2}$ On the other hand, some countries, particularly in Western Europe, argue that civilians fleeing conflicts should not be granted full refugee status. As a result, they have developed different forms of temporary/subsidiary humanitarian protection for these people. These alternative hosting schemes have been used in Europe to respond to sudden and massive influxes of war-displaced individuals (e.g., from the 1990's conflicts in the former Yugoslavia and Kosovo). In these cases, each civilian belonging to a certain group is considered a refugee prima facie (i.e., in the absence of evidence to the contrary), eliminating the need for individual status determination. Such group determination permits speedy admittance to safe countries but with no guarantee of permanent asylum.

At the same time, because the GCR does not stipulate how receiving countries should determine whether an individual meets the criteria for refugee status, each signatory country employs its own procedures for status recognition, with many (especially in the developing world) still lacking any formalized system. ${ }^{3}$ Similarly, although the GCR clearly states the rights and entitlements of

\footnotetext{
${ }^{2}$ For instance, the African Union (formerly the Organization of African Unity) adopted the "Convention Governing the Specific Aspects of Refugee Problems in Africa" in 1969 while the Organization of American States signed the "Cartagena Declaration on Refugees" in 1984. In both cases, the 1951 GCR definition was expanded to include those compelled to leave their country owing to such threats as external aggression, occupation, foreign domination, or generalized violence.

${ }^{3}$ Turkey, for instance, did not establish a legal framework for asylum and create an agency responsible for assessing asylum applications until 2013. Syrian refugees, however, are managed outside this system and benefit from a groupbased temporary protection scheme.
} 
refugees - access to courts (art. 16), labour market (art. 17-19), housing (art. 21), public education (art. 22), and so forth - it limits the enjoyment of these benefits to "refugees lawfully staying" in the host country territory (and thus not to current and rejected asylum seekers). It also uses overly broad formulations (e.g. "treatment as favourable as possible"), which leave much room for host state interpretation. Not surprisingly, such breadth has resulted in disparities as the different governments adapt their asylum laws to their own resources, refugee migration histories, and political and national security concerns (see section 2.4).

\subsection{From displacement to refugee status}

In Figure 1, we reconstruct the progression from displacement from region of residence to eventual recognition as a refugee in a third country. Those who flee their homes are technically defined as "displaced persons", reflecting their displacement by such traumatic events as violence, conflict, or natural disaster, and are classified by the UNHCR as their "population of concern". These individuals may be divided into those who are "internally displaced" (IDPs) - that is, forced to leave their homes but still residing in the country of origin - and those who have moved to a third country. These latter can be further divided into those who have moved to a neighbouring country ("first asylum country") and those who have managed (either legally or illegally) to reach a country that accepts asylum applications and offers GCR refugee status or other forms of humanitarian protection ("final destination" country). Obviously, these three outcomes can also represent consecutive steps in the same process.

In general, displaced persons in neighbouring countries are hosted in refugee camps but, not being subject to a formal status determination process, do not usually have recognized refugee status. UNHCR defines these individuals as being in a "refugee-like" situation, as belonging to "groups 
of persons who are outside their country or territory of origin and who face protection risks similar to those of refugees, but for whom refugee status has, for practical or other reasons, not been ascertained" (UNHCR, 2015). In fact, “first asylum" countries receiving inflows of displaced persons are often developing countries that do not - and usually cannot afford to - have any formal system in place to manage and assess asylum applications. Displaced people in refugee camps are thus often subsidized by UNHCR, non-governmental organizations (NGOs), and international aid and can remain in that situation for years. For these persons, UNHCR operates "resettlement schemes" that transfer refugees from one host country to another that has agreed to admit them and ultimately grant them permanent settlement. Candidates for resettlement undergo a formal refugee status determination process while still in the origin or first asylum country, after which successful candidates are relocated to the destination countries. A major advantage of the resettlement schemes is that displaced people do not need to engage in dangerous and illegal trips in order to find a safe haven abroad. Currently, however, only a relatively small number of states participate in the UNHCR resettlement program, with the U.S. being the world's top resettlement country, followed by Australia, Canada, New Zealand, and the Scandinavian countries.

Only a relatively small fraction of the total displaced population manages to reach a country that has a formal system of refugee status recognition (see also Hatton, 2009). These arrivals are usually unauthorized border crossings using forged documents and/or the help of smugglers. Once arrived in the host country, displaced persons have the right to apply for asylum and reside in the host country until a decision is made. The process outcome can either be recognition of full Geneva refugee status, the offer of some form of temporary humanitarian protection, or a rejection. Rejected asylum seekers have to either leave the host country autonomously or be returned to their home country. For many, however, the principle of non-refoulement applies, preventing the host 
country from expelling these individuals but leaving them with an undefined status (which often leads to undocumented residency). In general, return to the home country, although not represented in Figure 1, is an option at all stages of the process.

In its own records, UNHCR counts as refugees all individuals residing in a third country who are in a refugee-like situation, who enjoy formally recognized refugee status (under the GCR, 1967 Protocol, or any of the regional conventions on asylum), or who have been granted complementary and temporary forms of protection (UNHCR, 2015). Hence, throughout the remainder of the paper, we adopt their broad definition of refugees but distinguish individuals with refugee-like status from those with recognized refugee status whenever needed.

\subsection{Displaced population, refugees and asylum seekers: evidence from UNHCR data}

Table 1 provides an overview of the worldwide population of displaced individuals. The table shows that, as of 2015, most of the almost 59 million displaced individuals worldwide were still residing within the borders of their home countries; only $30.7 \%$ had left their country to become refugees abroad. For European (2.7 million) and South American (7.8 million) displaced persons, this share is 25.7 and $8 \%$, respectively, but for the 19 million Africans and 29 million Asians displaced by conflict or violence, it reaches 31.6 and $36.5 \%$, respectively. It is also worth noting that, as the bottom panel of Table 1 shows, most of these international movements involve neighbouring countries located on the same continent. For instance, in 2015 , almost $82 \%$ of African refugees were residing in another African country, while the corresponding values for Asian, European, and South American refugees were 81, 94, and 54\%, respectively. Europe as a whole was, in 2015 , hosting $15 \%$ of the world's refugees.

Figure 2 plots the time series of world refugee population (in millions) by continent of origin. The stock of refugees has been large over the entire 1980-2015 period. Nevertheless, large differences 
exist between continents, with refugee populations originating mostly from Asia and Africa dwarfing refugee populations from South America and Europe, including those induced by the Balkan wars. The figure also illustrates two notable peaks in the total refugee population, one in the early 1990s and the other in the 2010s, with a further rapid surge in the most recent years. The first peak, when the total refugee population reached 15 million people, was related to the Balkan wars and to conflicts in Africa (Rwanda, Somalia) and Asia (Iraq, Afghanistan). The second peak, starting around 2008, corresponds to the conflicts in Afghanistan and Iraq, and to the consequences of the Arab Spring uprisings in North Africa. The 2014-2015 surge is mostly explained by the Syrian civil war. The graph further shows that in 2015, Asian citizens accounted for more than 9.5 million refugees and African refugees for over 5 million, with the remaining million equally split between European and South American refugees.

In Figure 3 we report the total number of asylum applications (in millions) worldwide in each year between 2000 and 2015, distinguishing again by continent of origin. From a global figure of over 0.5 million asylum applications per year in the 2001-2002, this number declined to approximately 0.3 million per year between 2004 and 2010 and then began increasing sharply. In 2015, more than 2 million asylum applications were filed worldwide, a clearly unprecedented number given the just over 850,000 that made up the 1992 peak (Hatton, 2016). In 2015, the majority of asylum seekers originated from Asia (due especially to Syrian and Afghan asylum seekers), which accounted for almost 1.6 million applications.

In Table 2, we draw on the latest available UNHCR figures, updated to December 2015, to show the estimated number of Syrian citizens at different stages of the process that goes from displacement to being recognized as refugee. Of a total population of almost 22 million people (in 2011), almost 12 million of Syrian citizens (54\%) are currently displaced by the conflict. Slightly 
more than half of them (6.6 million) are still in Syria, being internally displaced. Just $1.5 \%$ (180 thousand) have been offered resettlement or resettled to a safe host country. The remaining $43.2 \%$ (5.1 million) have autonomously reached a third country. The vast majority of this latter group $(89 \%$; 4.6 million) is hosted under a refugee-like status in a neighbouring country: 2.5 million in Turkey, 1 million in Lebanon, 630 thousand in Jordan, 240 thousand in Iraq, and 120 thousand in Egypt. About half a million Syrians have reached an EU country and were granted asylum or are waiting for their asylum claim to processed: $40 \%$ of them are hosted in Germany (200 thousand), followed by Sweden (100), Austria (30) the Netherlands (30) and Hungary (20).

As for the case of Syrian citizens, UNHCR resettlement schemes still account for a relatively minor fraction of the refugee flows. The UNHCR estimated that over 1.1 million of refugees are globally in need of resettlement in 2016 (UNHCR, 2015b). The latest records show that 26 countries admitted a total of 105,200 resettled refugees in 2014, leading to a total of 900 thousand resettlements over the last decade (UNHCR, 2015). The United States are by far the major recipient of resettled refugees. In 2014, US admitted 73 thousand refugees ( $70 \%$ of the total), followed by Canada (12\%), Australia (11\%), Sweden (2\%), Norway and Finland (1\% each).

\subsection{Asylum policy in Europe}

\subsubsection{Towards a common European policy}

In the late 1980s and early 1990s, the gradual fall of the Iron Curtain triggered massive acrossstate movements that particularly affected Western European countries. The collapse of former Yugoslavia and the conflicts that tore apart the region for almost a decade generated additional flows of people seeking asylum. These large refugee inflows across Europe created a need to rethink asylum policies in all European countries. They also generated a shift towards a higher degree 
of coordination at the EU level. For example, since the 1990 adoption of the Dublin Convention, the EU has tried to develop a common European asylum system with the principal aim of clarifying which receiving country is responsible for asylum claims and preventing multiple application submissions in member states. The convention itself, which came into force in 1997-1998, established the principle that the member state through which the asylum seeker first entered the EU is responsible for assessing the asylum claim. To ensure effective application of the convention, in 2000, the EU approved the EURODAC Regulation, which established a common asylum fingerprint database. Between 1999 and 2005, several additional legislative measures were implemented to harmonize common minimum standards for asylum. In 2000, for instance, the European Refugee Fund (ERF) was created to share the costs of reception, integration and voluntary repatriation of people in need of international protection. The ERF was endowed with $€ 630$ million over the period 2008-13 (105 million per year), In 2014, the ERF was replaced by the Asylum, Migration and Integration Fund (AMIF), which has a budget of $€ 3.137$ billion for the seven years $2014-2020$, or $€ 448$ million per year. ${ }^{4}$ It is worth noting, that the resources targeted to these funds are relatively small when compared to other EU funds. For instance, the European Social Fund (ESF) receives a funding of $€ 10$ billion a year, ${ }^{5}$ and the European Agricultural Fund for Rural Development (EAFRD) has been endowed with $€ 100$ billion over the seven years 20142020 , or $€ 14.2$ billion per year. ${ }^{6}$

Yet despite these persistent attempts to establish a single and harmonized European asylum policy, individual member states have de facto maintained full sovereignty over the implementation of their national asylum policies. In addition, as highlighted by the current refugee crisis, the

\footnotetext{
${ }^{4}$ http://ec.europa.eu/dgs/home-affairs/financing/fundings/migration-asylum-borders/index en.htm

${ }^{5} \mathrm{http} / / /$ ec.europa.eu/esf/main.jsp?catId=35\&langId=en

${ }^{6} \mathrm{http} / / /$ ec.europa.eu/agriculture/rural-development-2014-2020/index_en.htm
} 
European common policy on asylum is riddled with weaknesses. One notable example is the socalled EU "refugee relocation system" based on a September 2015 EU agreement to relocate 160 thousand refugees from Italy and Greece to other European countries over a period of two years. Because several countries voted against the scheme and refused to participate, as of 15 September 2016 , only $9 \%(14,478)$ of the promised 160,000 places have been made available by some of the participating countries and less than 5\% (4,890) of the refugees have actually been relocated. ${ }^{7}$

\subsubsection{Heterogeneity in asylum policies across Europe}

The different exposures to refugee inflows (see section 3.3) and the lack of an effective Europeanlevel mechanism to "spread the burden" of hosting refugee populations, led many countries to implement procedures aimed at reducing inflows into their territories. One such strategy is to tighten visa requirements and border enforcement to reduce the number of asylum seekers that manage to reach the territory and apply for refugee status. Another is to vary the efficiency of application assessment and/or become stricter about granting protection to applicants. Governments can also decide whether to grant full GCR refugee status or to offer subsidiary forms of humanitarian protection. They can also greatly impact the treatment given to asylum seekers and refugees by regulating and limiting their access to such advantages as benefit entitlements, the labour market, and choice of residence. In this section, we document this heterogeneity using both UNHCR data and a summary of national legislative differences.

UNHCR data (see Data Appendix A.1) permit the construction of informative indicators of the efficiency and "generosity" of national asylum policies. First, because governments may try to discourage potential refugees by under-investing in the staff and resources for screening - thereby

\footnotetext{
${ }^{7}$ http://ec.europa.eu/dgs/home-affairs/what-we-do/policies/european-agenda-migration/pressmaterial/docs/state of play - relocation en.pdf, accessed on 19 September 2016.
} 
prolonging wait times and increasing outcome uncertainty - we use share of applications evaluated over total submitted each year to compare the speed and efficiency of application processing in different countries. We illustrate the pace of processing applications in Figure 4, whose vertical axis reports the yearly average of the application shares processed in EU15+NOR+CHE countries over the 2000-2014 period. This share varies from a minimum of $37 \%$ in Greece to a maximum of $73 \%$ in the UK, with an overall average of approximately $57 \%$. These numbers imply that it takes Greece an average of almost 3 years to process all applications received in any given year, while the UK takes less than 1.5 years. The figure also suggests that the pace of application processing is not mechanically determined by the number of applications received (per 10,000 population), which are reported on the horizontal axis. In fact, the numbers of applications processed each year in the three countries that have received the largest inflows of applicants (relative to population) in the last 15 years - Sweden, Norway, and Switzerland - are close to, or even above, the European average. On the other hand, among the three countries that received the smallest inflows, Portugal and Italy have processing times close to the European average (both around $60 \%$ ) while Spain only manages to assess $47 \%$ of its yearly application inflow. While some of the cross-country variations in processing time could be due to differences in the composition of asylum applications, ${ }^{8}$ the absence of a correlation between processing time and number of applications received suggests that countries can choose their own application processing pace and that those receiving larger inflows probably invest more resources in their screening processes.

Figure 5 demonstrates that European countries also differ widely in their asylum generosity, which we measure here as the "total recognition rate", the number of positive decisions to grant

\footnotetext{
${ }^{8}$ Some countries, for instance, may systematically receive more applications from a group of potential refugees that are inherently harder to evaluate, slowing down the screening process.
} 
some form of humanitarian protection (GCR refugee status or other subsidiary protection) over the total number of applications processed. On average, only about $10 \%$ of applications submitted in EU15+NOR+CHE countries between 2000 and 2014 led to recognition of refugee status. This share, however, varies from as little as $2 \%$ in Greece to approximately $18 \%$ in Denmark. Nevertheless, the figure shows a positive correlation (fitted line) between yearly shares of applications processed and recognition rates: countries that are more efficient in screening applications tend also to be more generous in offering refugee status. ${ }^{9}$ This positive slope suggests that European countries that are faster in screening applications are not achieving this target simply by rejecting more applicants. On the contrary, countries like Belgium, France, Denmark, and the UK seem to combine a relatively high degree of both efficiency and generosity.

As discussed in section 2.1, national governments maintain a substantial degree of discretion in deciding upon the exact status to be granted to asylum applicants. Using UNHCR statistical data, we can measure the "Geneva refugee recognition rate" as the share of applicants accorded full GCR refugee status over the total granted some form of humanitarian protection. Table 3 reports the total number of asylum applications approved by each country in 2014, together with the share of individuals approved for full GCR status. In 2014, 204,092 asylum applications were approved in EEA countries, the vast majority in a Western European country. Of these, $58 \%$ were given full GCR refugee status, while the others received only subsidiary protection. There is, however, considerable heterogeneity in the frequency of refugee status across countries: whereas Italy, the Netherlands, and Spain, for instance, granted GCR status to less than $25 \%$ of total successful applicants, this share was around $80 \%$ in Austria, Belgium, and Germany and $91 \%$ in the UK.

\footnotetext{
${ }^{9}$ Austria and Germany appear as outliers in this graph, having relatively high recognition rates but also relatively long processing times.
} 
These differences, although possibly indicative of different interpretations of the common legal framework, may also be due to differences in the type of applications received. For this reason, in columns 3-4 and 5-6 of the table, we focus on Syrian and Afghan refugees, respectively. Once again, we observe substantial heterogeneity in the treatment of refugees from the same origin countries, with Syrians more likely to receive full GCR status than Afghans in almost all receiving countries. Nevertheless, even though in countries like the UK (97\%) and Austria (91\%), almost all Syrian refugees are given full Geneva status, this share is as low as $10 \%$ in large destination countries like Sweden. The GCR status recognition rate for Afghan refugees similarly varies from $85 \%$ in the UK to $10 \%$ in Italy.

National asylum policies can also vary along many other dimensions, a few examples of which we summarize in Table 4 at different stages of the process. ${ }^{10}$ National governments can, for example, employ lists of "safe countries of origin" to accelerate asylum application screening, which in the case of EU member states means all other member states (plus Switzerland and Norway) as safe countries of origin. In general, to qualify as a safe third country, a nation must implement the GCR and offer potential refugees the opportunity to apply for asylum. ${ }^{11}$ Yet only eight EU countries Austria, Belgium, Denmark, Germany, France, Ireland, Luxembourg and the UK - have adopted official lists of safe origin countries outside the EU, and even these lists vary widely in both number and countries included. For example, whereas Ireland's list contains only one country (South

\footnotetext{
10 The European Council on Refugees and Exiles (ECRE; http://www.ecre.org/) recently created an Asylum Information Database (AIDA) containing information on asylum procedures, reception conditions, and detention across 16 EU member states. This database provides a clear picture of the current heterogeneity in policies across these states and is one of the main sources used here.

${ }^{11}$ In a highly controversial decision, Norway's parliament agreed in November 2015 to amend the Immigration Act, removing the requirement that a country accept and process asylum applications to be considered a safe third country. This change implies that Russia can be deemed safe to receive asylum seekers and allows Norway to forcedly deport asylum seekers entering through the Artic border with Russia (the "artic route"). In similar manner, a March 2016 EU agreement with Turkey implies that Greece can consider Turkey a safe country, allowing Greece to transfer asylum seekers from its territory to Turkey's.
} 
Africa), the UK's includes 26 countries. Of these, Bosnia and Herzegovina (BIH) and the Former Yugoslav Republic of Macedonia (MKD) are considered safe by all list adopters except Ireland. Albania (ALB) and Montenegro (MNE) are considered safe by all but Germany and Ireland, and Kosovo (RKS) is deemed safe by Austria, Belgium, Denmark, Luxembourg, and the UK, but not by France, Germany, or Ireland. A related concept, central to the Dublin Convention, is the "safe third country", a construct used to justify the rejection of applications from asylum seekers who transited through a safe country (where they could have applied for asylum) and subsequent forced return to that country.

All EU countries tend to impose restrictions on asylum seekers' labour market access, a constraint intended to reduce incentives for economic migrants to submit (unfounded) asylum applications. In general, asylum seekers are prevented from being (legally) employed for a minimum period that should theoretically correspond to the time required to process their claims. According to EU Directive 2013/33, member states must ensure that asylum seekers access the labour market no later than 9 months after they apply for protection. This ban, however, is for only 1 month in Portugal; 3 months in Austria, Finland, and Germany, 6 months in Belgium, Italy, Netherlands, and Spain, but one year in France and the UK.

Over the last few decades, European countries have also experimented with asylum seeker dispersal policies aimed generally at distributing the inflows of potential refugees across different regions of the receiving countries, usually away from major cities. Sweden, for example, introduced an "all-of-Sweden" policy in 1984 that remained compulsory until 1994 (Edin et al., 2003). Denmark similarly implemented a dispersal policy between 1986 and 1998 (Damm, 2009), and in 1987 and 1994, respectively, the Netherlands and Norway introduced dispersal policies that still remain in place today. The UK and Ireland also continue to disperse asylum seekers under 
policies introduced in 2000 (Bell et al., 2013). At the same time, according to AIDA ${ }^{12}$ survey data, only Belgium, Italy, and Ireland fully guarantee asylum seekers adequate access to health care: in all other countries, they enjoy only limited access.

\section{The current European refugee crisis}

\subsection{Entry routes}

According to Frontex, which records detected attempts since 2009, over 2.6 million illegal migration attempts were detected at European borders between 2009 and 2015, with 1.8 million in 2015 alone. ${ }^{13}$ Frontex distinguishes nine routes of entry into Europe: (1) the central Mediterranean route (i.e. flows from North Africa towards Italy and Malta through the Mediterranean Sea); (2) the circular route from Albania to Greece; (3) the eastern border route (i.e., the 6,000 km long land border between Belarus, Moldova, Ukraine, the Russian Federation, and the EU's eastern member states); (4 \& 5) the Eastern Mediterranean sea and land routes (i.e. crossing through Turkey to the EU via Greece, southern Bulgaria, or Cyprus); (6) the Western African route (mainly from Senegal and Mauritania to the Canary Islands); ( $7 \& 8$ ) the western Mediterranean sea and land routes (from North Africa to the Iberian Peninsula); and (9) the Western Balkan route (i.e. flows from the Western Balkan countries themselves and crossings through the Bulgarian-Turkish or GreekTurkish borders directed towards Hungary).

Figure 6 outlines the numbers of illegal border crossings recorded by Frontex over time while also highlighting the share of crossings through each of the three routes that have become the most important in the current crisis: the Central Mediterranean route, the Eastern Mediterranean sea

\footnotetext{
${ }^{12}$ The European Council on Refugees' Asylum Information Database (AIDA).

${ }^{13}$ Illegal crossings are defined as "the number of third-country nationals detected by Member State authorities when entering or attempting to enter illegally the territory between border crossing points at external borders". See Data Appendix A.2 for a discussion of the limitations of these data.
} 
route, and the Western Balkan route. The number of attempted illegal crossings rose dramatically between 2014 and 2015. The share of total crossings along the Central Mediterranean route was especially large in 2014 (about $60 \%$ of total crossings), while the Eastern Mediterranean sea and Western Balkan routes together accounted for $90 \%$ of illegal crossing attempts in 2015 .

\subsection{Source countries}

As regards origin country, over the entire $2009-2015$ period, Syrian citizens, at about $38 \%$ of the total, constituted the largest group attempting illegal crossings, with the over 500 thousand Afghans making up an additional 20\% (see panel A, Table 5) ${ }^{14}$. Iraqis, Pakistanis, Albanians, and Eritreans each accounted for 4 to $5 \%$ of total crossings, while those coming from Kosovo, Somalia, Nigeria, and Bangladesh made up about $2 \%$. As illustrated by the ratio of illegal crossing attempts in 2015 to those in 2009 (column 4), over the 7 years covered by our data, the relative magnitude of inflows from each of these countries varied drastically, and total illegal crossing attempts grew 17 fold. Nonetheless, expansions were not equally distributed across countries; for instance, unauthorized migration attempts from Syria accelerated dramatically from barely any in 2009 to 1.4 thousand times the number in 2015 . Conversely, the number of illegal crossings attempted by Albanian citizens in 2015 was only one third of its 2009 size.

Panel B of Table 5 shows that, between 2009 and 2015, over 3.5 million asylum applications were submitted in Europe, with the number increasing nearly fivefold over the period. The top 10 countries of origin for asylum applicants largely overlap with those of illegal crossers, with 9 out of 10 countries being in both lists. Syria and Afghanistan particularly, the two countries that account for the greatest number of attempted illegal border crossings, are also the top two countries

\footnotetext{
${ }^{14}$ Because information on origin country is unavailable for $14 \%$ of total crossings in Q3 2015 and $48 \%$ of total crossings in Q4 2015, for these two quarters, we impute unknown nationalities based on the route-specific origin country composition in the previous quarter.
} 
of origin for asylum applicants and were responsible for the largest increase in asylum applications (by a factor of 77 and 8, respectively). The exceptions are Russia, which is only present among countries of origin for asylum applicants, and Bangladesh, which is not among the top ten countries of origin of asylum applicants.

\subsection{Destinations}

As already emphasized, not all European countries (EU28 + NOR + CHE) have been equally affected by the refugee crisis. As Table 6 shows, between 2009 and 2015, Western European countries received the largest share $(3.1$ million) of the total 3.5 million asylum applications (almost 70 per 10,000 population) received by all European countries. ${ }^{15}$ These aggregate figures, however, conceal the true heterogeneity of refugee populations across Western European countries. As Table 6 shows, over the 2009-2015 period, the top 5 recipients of asylum applications were Germany (902 thousand; 110.1 per 10,000 pop.), Sweden (414 thousand; 446.9 per 10,000 pop.), France (390 thousand; 60.5 per 10,000 pop.), Italy (256 thousand, 43.5 per 10,000 pop), and Hungary (244 thousand; 243.8 per 10,000 pop.).

Figure 7 illustrates the relation between the total asylum applications received by each country between 2009 and 2015 (vertical axis) and its population of individuals with refugee status in 2009 (horizontal axis). The straight line is the equality line. The figure shows that the vast majority of European countries - with the only exception being the UK - lie above the equality line, implying that the number of applications received over the 2009-2015 period was larger than the accumulated stock of refugees hosted in 2009. The scatter plot further reveals that countries that

\footnotetext{
${ }^{15}$ Note that the figures refer to the number of applications, not the number of individuals filing an application. Since individuals may be filing multiple applications, the number of applications is an upper bound for the actual size of the flow of asylum seekers over the period.
} 
started with a larger population of refugees in 2009 attracted more asylum applicants in the following years.

As a matter of fact, the burden imposed on Europe by this inflow of asylum seekers is small compared to that placed on countries closer to the refugees' countries of origin. This difference is clearly demonstrated in Table 7, which reports refugee stocks and their ratios to 10,000 population in both selected EU countries and Syria's neighbouring countries in 2014 (the last year for which complete data are available for all countries). At that time, Lebanon, a country with a population of 4.5 million, was hosting 1.16 million refugees, or about 2,554 individuals in search of humanitarian protection per 10,000 population. Likewise, Jordan was home to more than 1,000 refugees per 10,000 population, while Turkey was hosting nearly 1.7 million or 221 per 10,000 population. By comparison, Sweden, the EU country with the highest population of individuals with full GCR or subsidiary status relative to its size, was hosting 206 asylum seekers or individuals with refugee status per 10,000 population. The ratio for Norway and Switzerland was just above 100 per 10,000 population, and for Germany and France, it was only 55 and 47, respectively.

\section{Refugee labour market integration 4.1 Evidence from past refugee waves}

To assess how well past refugees to EU countries have integrated into the labour market compared to economic immigrants from the same area of origin we draw on the 2008 wave of the European Labour Force Survey (EULFS) that allows us to differentiate between economic and refugee migrants. ${ }^{16}$ We focus on individuals in working age (between 25 and 64 years old), not in full

\footnotetext{
${ }^{16}$ At the time this paper was written, this is the only available wave in the EULFS that provides that type of information.
} 
education or military service, and define "refugees" the migrants who report "international protection" as the reason for migration (see Data Appendix A.3 for details).

Table 8 gives an initial overview of the socio-economic characteristics of refugees compared to those of natives and economic immigrants from EU15 and non-EU15 countries. The refugees are $61 \%$ male, versus $47 \%$ for economic immigrants, and 43.9 years old on average, which is slightly older than economic immigrants but under a year younger than natives. They are on average somewhat less educated than natives and economic immigrants from EU15 countries, but they are better educated than economic immigrants from non-EU15 countries.

To evaluate how refugee employment rates compare with those of economic immigrants and natives, in Figure 8, we graph unconditional and conditional (on age, gender and educational attainment) employment rate differentials between natives and, respectively, EU15 economic immigrants, non-EU15 economic immigrants, and refugees overall. ${ }^{17}$ Although all immigrant types have lower employment probabilities than natives, both conditionally and unconditionally, the employment gaps are larger for non-EU15 immigrants than for EU15 immigrants (3.2 vs. 7.2 percentage points unconditional on socio-economic characteristics) and increase to 16.1 percentage points for refugees. Conditional employment gaps are even larger, reflecting the fact that refugees are disproportionately male and young, both of which characteristics are positively associated with a likelihood of employment. Figure 9 provides more detail on how the (conditional) immigrant-native and refugee-native employment gaps differ by area of origin. ${ }^{18}$

\footnotetext{
${ }^{17}$ The estimates are from LPM regressions of an indicator equal to one if the individual is employed (or self-employed) on refugee, EU15 immigrant, and non-EU15 immigrant dummies, a set of individual controls, and country of residence fixed effects. These estimates are reported in Appendix Table A1. We focus our analysis of refugees' economic integration on employment status because wage data are not available in EULFS data.

${ }^{18}$ The estimates are from LPM regressions of an indicator equal to one if the individual is employed (or self-employed) on refugee and immigrant dummies, a set of individual controls, and country fixed effect, with separate regressions estimated for each area of origin. Information about the country of origin is not available. These estimates are reported in Appendix Table A2.
} 
Whereas refugees and economic immigrants from European countries outside EU15 (NMS12 and Other European in the Figure) show similar conditional employment gaps to natives, refugees from North Africa, the Middle East, or other African and Asian countries are considerably less likely to be employed than economic immigrants from the same areas of origin. Employment gaps are largest for the group of refugees from North Africa and the Middle East, at 32.5 percentage points.

To assess how quickly refugees integrate into their host countries vis-à-vis economic immigrants, in Figure 10 we plot the conditional refugee-native and immigrant-native employment rate differentials against years since arrival. As expected, the employment probabilities of both refugees and economic immigrants increase with years in the country; however, the increase is far steeper for refugees. During the first 3 years of arrival, refugees are 50 percentage points less likely to be employed than natives, a large gap that may be explainable by the legal restrictions on labour market participation frequently in place during the application processing period. This refugeenative employment gap declines by about half 7 to 10 years after arrival, turns statistically insignificant 15 to 19 years after arrival, and eventually approaches zero 25 years after arrival. While the figure suggests that employment prospects of refugees improve more rapidly than those of immigrants with time in the country, it is important to bear in mind that the figure is based on one cross-section only, precluding us from separating the effects of years since arrival from possible compositional changes across cohorts. This catch-up of refugees is in line with evidence presented by Aiyar et al (2016) who, similar to us, focus on Europe as a whole. Luik et al. (2016) and Cortes (2004) document a similar catch-up of refugees in Sweden and the US. Bratsberg et al. 
(2014, 2016), in contrast, paint a more negative picture in the case of Norway, highlighting that refugees become increasingly dependent on social insurance transfers. ${ }^{19}$

Table 9 highlights that the lower employment probabilities of refugees versus immigrants cannot be accounted for by differences in area of origin or years since arrival. ${ }^{20}$ Conditional on individual characteristics and destination country fixed effects, refugees are 10.9 percentage points less likely to be employed than economic (non-EU15) immigrants. This gap decreases only slightly to 0.095 percentage points when area of origin fixed effects and years since arrival are included as additional regressors. Compositional differences in terms of years since arrival and areas of origin are therefore responsible for only a relatively small portion $(13 \%)$ of the observed employment gap between refugees and non-EU15 immigrants.

Figure 11 further reveals that the refugee-native employment gaps (conditional on individual characteristics) vary widely across destination countries, much more so than the economic immigrant-native employment gaps. The two countries with the largest refugee-native employment gaps are Ireland and the UK (with 46 and 29 percentage points, respectively), both nations in which economic immigrants do particularly well ${ }^{21}$. Countries with a relatively large refugee share, such as Sweden, Germany, and Austria, take a middle position with employment

\footnotetext{
${ }^{19}$ Bevelander and Pendakur (2014) find that in Canada refugees, especially women, tend to be more successful than family reunion immigrants.

${ }^{20}$ In column (1), we regress the employment indicator on an indicator for being a refugee, an indicator for being foreign-born (which equals 1 for both immigrants and refugees, and 0 for natives) as well as on individual characteristics and country of residence fixed effects. We then include a full set of interactions between the foreignborn indicator and indicators denoting years since arrival (column 2), between the foreign-born indicator and indicators of area of origin (column 3), and between the foreign-born indicator and indicators of both years since arrival and area of origin ones (column 4). In this specification, the coefficient on the refugee indicator refers the mean difference in the employment probabilities of refugees and non-EU15 immigrants within each year since arrival (in column 2), within each area of origin (in column 3 ) or both (in column 4).

${ }^{21}$ Despite such heterogeneity, estimates from the pooled sample of all countries are not driven by any single country. Table A3 reports estimates from pooled regressions where we drop at a time each of the countries in our sample. The immigrant and refugee coefficients remain highly significant and are of similar magnitude across all specifications.
} 
gaps of 23, 17 and 9 percentage points respectively. Finally, employment gaps between natives and both refugees and economic immigrants are small in Cyprus and Greece, as well as in Italy, Spain, and Portugal, all countries with relatively low shares of refugees.

\subsection{Outlook: The current refugee crisis}

How well current refugees will integrate into the labor market is extremely difficult to forecast for at least two reasons. First, comprehensive and representative data on the skill structure and employability of those currently applying for asylum, or of those whose application was approved no more than 2 years ago, does not yet exist. Second, their labor market outcomes depend on which policies, integration support, and incentive structures are implemented.

As Figure 9 shows, existing refugee populations in EU member states who arrived many years before the current crisis, but who are from the same areas as the major share of current asylum seekers (i.e., North Africa and the Middle East), are considerably less likely to be employed than refugees from other areas, even conditional on their educational background.

A recent survey by the German Ministry for Immigration and Refugees conducted in 2014, which focuses on individuals given official refugee status who initially applied for asylum in Germany between 2007 and 2012 and thus arrived at the onset of the crisis, further indicates that refugees from Syria, Iraq, and Afghanistan are less educated than refugees who arrived in previous waves. Specifically, as Table 10 shows, $16.1 \%$ of Syrian and $25.9 \%$ of Iraqi refugees have never attended school, and only 4.3 and $3.5 \%$ have attended school for at least 15 years (which is comparable to tertiary education in Table 8 ). The table further shows that only $38.9 \%$ of Iraqi and $24.7 \%$ of Syrian refugees are employed (of which roughly one third are employed only marginally for under 10 
hours a week), while one fifth to one quarter are looking for work (see Worbs and Bund, 2016, for more details).

Focusing on refugees who applied for asylum in Germany in 2015, a survey conducted by the German Ministry for Immigration and Refugees at the time of registration paints a somewhat more optimistic picture and puts the share of asylum applicants with tertiary education at $17 \%$ and the share of applicants who never attended school at $8 \%$. These numbers may, however, not be fully representative as only $70 \%$ of asylum applicants agreed to participate in the survey.

\section{The economics of refugee migration}

We begin our discussion on the economics of refugee migration by highlighting the important differences between refugee and economic migrants (section 5.1). We then discuss the trade-offs and policy options faced by single countries (section 5.2) before outlining the economic advantages of coordinated decisions between countries; for example, at the EU level (section 5.3).

\subsection{Refugee vs economic migrants}

Economic migrants are, at least conceptually, fundamentally different from refugee migrants in that the former not only choose whether or not to migrate but also decide, based on the constraints set by receiving countries, which country to migrate to given the economic benefits of this decision. Refugee migrants, in contrast, are forced to leave their origin countries, often due to unforeseen and sudden events that put their lives at risk. Their migration decisions, therefore, are generally neither deliberate nor planned, and less based on economic considerations. Their arrival in a host country is often dictated by contingency, after perilous and unpredictable journeys. Similarly, receiving countries typically choose economic migrants based on economic considerations (e.g. labour market shortages) and they can set clear migration terms, such as stay 
duration and migrant qualifications. In the case of refugee migration, however, countries are fulfilling their obligations as GCR signatories, and the decision to grant asylum seekers official refugee status is primarily based on humanitarian considerations. As such, receiving countries may have relatively little influence on the type of refugees they host. Refugee migrations are therefore closer to "forced marriage" than the "chosen match" typical in economic migrations and the relation between the two parties, migrant and destination country, is different from what would have evolved if all decisions had been taken on purely economic grounds. This is not to say that the forced marriage is necessarily inferior to the optimally chosen match for both parties. On the contrary, forced emigration may well mean that destination countries are able to attract migrants with qualifications and economic potential that they might otherwise not have enticed to settle in their countries. ${ }^{22}$ Cases also exist, however, of less well-endowed refugee populations where the economic benefit to the receiving country is less clear - see our discussion in the previous section.

\subsection{Country-specific policies and tradeoffs}

\subsubsection{Permanent settlement or temporary protection?}

Even though destination countries have limited control over the number and type of displaced migrants arriving in their territory, they can decide whether to grant full GCR refugee status or offer subsidiary forms of humanitarian protection that require refugees to repatriate once the conflict or migration trigger has been eliminated. For instance, whereas in the 1990s, most destination countries opted for some form of temporary protection for the refugee waves from Bosnia and Kosovo, the choices made during the current refugee crisis differ widely (see Table 3).

\footnotetext{
${ }^{22}$ Historical incidences of the gains to countries giving refuge to persecuted populations include the 17 th century repopulation and boost to the textile industry in war-torn Prussia induced by Huguenots fleeing religious persecution in France (see Hornung, 2014) and the major contributions to science and technology in the US made by highly educated Jews fleeing Nazi Germany (see e.g., Moser, Voena, and Waldinger, 2014).
} 
Many of the former Yugoslavia refugees returned to their home country once the conflict ended. For example, of the 345,000 refugees from Bosnia-Herzegovina residing in Germany in 1996, 260,000 had voluntarily returned by December 2000, while 5,500 were deported against their will (Rühl and Lederer, 2001). In the current crisis, not only is there considerably more uncertainty about whether and when the primary impetuses for asylum seeking will abate, but current refugees are culturally more distinct than the Balkan refugees and, based on initial evidence, may also be less educated (see section 4.2).

Two primary reasons for the poor success in integrating refugees into the host countries' labour markets are the long decision time for asylum claims and the indecisiveness of host nations about duration and permanence of stay. Both factors contribute to considerable delays in giving individuals a clear perspective on their future residence in the host country. This lack of clear timeframe speaks to the key insight from early dynamic models of human capital (e.g., Ben-Porath, 1967) that the longer the pay-off period for skill investment, the more individuals invest, which is why full time schooling takes place at the start rather than in the middle or towards the end of an individuals' life cycle. Applied to migrants, because the type of human capital that is productive differs across nations, migrants must learn new skills that make them productive in their new country of residence. One such skill is knowledge of the local language, whose acquisition is very costly but of dubious value in the origin country. Consequently, as emphasized by Dustmann (1993, 1999, 2000), whether and how much a migrant chooses to invest into country-specific human capital depends greatly on the migrant's perception of the likelihood of future settlement in the host country. Being unclear about the chances of permanent stay creates disincentives for investment into the types of skills that are productive in the new country, affecting the refugees' 
earnings and career paths and leading them to perform below their economic potential. ${ }^{23}$ Lack of clarity about the possibility of permanent settlement thus obstructs attempts to use such schemes to train refugees. Even if permanent residence is guaranteed but only after a prolonged period in the host country, such investment may no longer seem optimal because of the reduced pay-off period. Adda et al. (2016) find strong support for this hypothesis, by estimating a dynamic model of return migration and human capital accumulation, and simulating the effects of lack of clarity about permanence at the start of an individual's migration cycle on lifetime earnings and human capital investments.

These observations have important consequences for the politics of refugee migration. Above all, policies aimed at fostering labour market integration and optimizing migrants' economic contribution need to recognize that these individuals will only undertake costly investments in host country-specific human capital if they are likely to pay off over the life cycle. Moreover, because certification requirements and the transferability of certain aspects of such capital differ across countries, any such policies need to be carefully adapted to the particularities of the host country. ${ }^{24}$ As a result of the above circumstances, refugees who are initially offered only temporary protection but end up staying for long periods may have lower employment probabilities and lower earnings than refugees offered permanent settlement from the start. This observation calls for

\footnotetext{
23 For example, Germany's comprehensive system of skill certifications obtained through 2-3 year trade apprenticeships is costly because remuneration during the long training period is far lower than the wage in an equivalent unskilled job (see Dustmann and Schoenberg, 2012, for details). Moreover, the certification, although valuable in Germany, may be worth little in the refugee's country of origin. Consequently, even young refugees are likely to be reluctant to undertake prolonged and costly training within the apprenticeship system unless they see their future in the Germany.

${ }^{24}$ For instance, whereas certificates are an essential part of German workers' careers, such is less the case for UK workers. On the other hand, English may be more valuable in the home country than German. All else being equal, both these aspects support the economic integration of refugees into the UK rather than Germany.
} 
shorter periods for deciding asylum claims ${ }^{25}$ and for policies that provide clear host country commitment on residence duration. Such policies should be combined with carefully designed active integration programs for those who obtain full refugee status or permanent residency. ${ }^{26}$ The refugees' own investments could be further incentivised by making economic success in the labour market a pre-condition or contingency in the selection for permanent residence. In fact, Germany adopted such a policy in the 1990s for refugees from Bosnia and Kosovo (see, e.g., Rühl, and Lederer, 2001; Rühl, Neske, and Currle, 2004).

\subsubsection{Where should refugees be allocated?}

In addition to choosing between permanent and temporary protection, destination countries must decide on refugee location, which economic efficiency dictates should be in areas with the lowest hosting costs but highest chances of integration into the labour market. Such areas tend to be urban areas already containing immigrants from the refugees' own country, who can then serve as a support network and actively help their newly arrived compatriots to find decent-paying jobs (Edin et al, 2003; Damm, 2009). For the same reasons, refugees also typically prefer areas with a larger concentration of their own nationals, meaning that allowing refugees free choice over where to locate within the destination country may lead to superior labour market outcomes.

Another important consideration is the political costs of refugee allocation. Recent research by Dustmann et al. (2016) suggests that the political costs may likewise be smaller in urban than in rural areas: they find that the inflow of refugee migrants increases the support for right-wing anti-

\footnotetext{
${ }^{25}$ Hainmueller et al. (2016) provide evidence that the length of time that refugees wait for a decision on their asylum claim affects their subsequent economic integration.

${ }^{26}$ Couttenier et al. (2016) provide evidence that integration policies, including swift access to the labour market, can mitigate immigrants' likelihood to commit a crime.
} 
immigration parties in rural areas, but not urban areas. On the other hand, housing costs are typically considerably higher in urban than in rural areas.

\subsection{Economic advantages of coordinated decisions between countries}

Increased coordination between countries - for example, at the EU level - could have several economic benefits for receiving countries that are separately discussed below.

Refugee status as a public good. Offering refugee status is a public good in that if one country offers asylum to those escaping individual persecution or civil war, residents in other countries benefit from knowing that these individuals are safe. However, the fact that the costs of hosting the refugees are borne entirely by the country providing asylum leads to an under-provision of the public good when countries make such decisions individually. Coordination between countries would make it possible to internalize the externalities that countries impose on each other, allowing the social optimum to be reached (see Hatton and Williamson (2006) and Hatton (2004, 2015), for a formal analysis). ${ }^{27}$

Dynamically consistent decisions. A lack of coordination may induce countries to make decisions that are not dynamically consistent. For example, governments may deter applications for asylum by adopting specific policies, such as limiting asylum seekers' access to the labour or housing markets, implementing an especially lengthy application process, or failing to provide an active integration program for successful applicants. These polices, as previously pointed out, can increase a destination country's cost of refugee hosting by hindering the integration of successful

\footnotetext{
${ }^{27}$ Facchini et al.(2006) develop a political-economy model to study the process through which countries determine their asylum policies. They show that coordination is desirable, but allowing for cross-country transfers toward countries that receive larger numbers of asylum seekers may lead to a welfare inferior outcome because the possibility of compensation exacerbates strategic delegation effects.
} 
applicants. If, however, countries cooperate, they no longer have any incentive to adopt such harmful policies.

Allocating a given number of refugees at the lowest possible cost. As shown by FernándezHuertas Moraga and Rapoport (2015a, 2015b), cooperation across nations makes it possible to allocate a given number of refugees at minimum costs while simultaneously ensuring that the burden (or responsibility) of providing refuge is shared by all countries. Supposing that countries have not only agreed on the total number of refugees to be admitted but also on a refugee quota system (based, e.g., on country population size and GDP), ${ }^{28}$ then, ignoring for the moment any match effects whereby certain types of refugees can best integrate in a particular country, these countries will differ with respect to their (marginal) costs of providing refuge. Here, we interpret "costs" in the broad sense, reflecting not only monetary costs but also the country's general willingness to welcome refugees. A market in which countries are allowed to trade refugee quotas will secure the allocation of refugees across countries at minimum costs. To illustrate this consider two countries, A and B, that initially agree to accept 1,000 refugees each. If the cost of hosting an additional refugee is $€ 20,000$ for country A but only $€ 10,000$ for country $B$, then there is room for trade. For example, country B might admit an additional refugee if paid at least $€ 10,000$, while country A might be willing to pay up to $€ 20,000$ for not having to provide refuge to the 1,000 th refugee. The gains from the trade will be exhausted once the marginal costs of hosting an additional refugee are equalized between the two countries, resulting in a refugee allocation that minimizes the costs of granting asylum and allows both countries to contribute to the costs according to a prearranged quota. $^{29}$ As argued by Fernández-Huertas Moraga and Rapoport (2015b), this

\footnotetext{
${ }^{28}$ Several such quota systems have been proposed in the past; see, for example, Fernandez-Huertas Moraga and Rapoport (2015a) for an overview.

${ }^{29}$ It should be noted that only a market mechanism can induce countries to truthfully reveal their costs of hosting refugees: when countries implement quotas dependent on costs, they have an incentive to overstate them.
} 
mechanism may be augmented by a matching algorithm that allows refugees to state their preferences for country of residence so as to realize match-specific gains between refugee and host country.

\section{Discussion and conclusions}

In this paper, we provide a comprehensive overview of the existing regulatory frameworks for refugee migration, the magnitudes and types of refugee movements, and the economics and politics of the current refugee crisis. In particular, we identify strong differences in the way EU countries interpret their obligations as signatories of the Geneva Convention for Refugees (GCR) and outline previous (mostly unsuccessful) attempts to enhance coordination at the EU level. We also demonstrate that although asylum claims in the EU are currently at an all-time high (1.5 million in 2015), applications are far from equally distributed across EU countries, and only about $10 \%$ submitted to EU15 countries (plus Norway and Switzerland) between 2000 and 2014 were successful. We further document that previous waves of refugee migrants have been less successful in integrating into European labour markets than economic migrants from the same origin areas. We also offer tentative evidence that the labour market outcomes of the current waves of refugees will be similarly problematic unless better integration mechanisms are implemented.

In our view, the above evidence calls for a strong, coordinated policy response to the current crisis, which has imposed on Europe the tremendous costs of large-scale movements of people who arrive unexpectedly and are - given current regulations and their common interpretations - hard to control using conventional border protection means. These movements pose an enormous challenge to European countries and to the fundaments of the EU as a whole. Not only their economic costs but also their political costs threaten to create rifts between countries and furnish 
a welcome vehicle for populist movements to enhance their vote shares. ${ }^{30}$ The current crisis further demonstrates that the Dublin Convention is unworkable, as amply illustrated by Europe's unpreparedness for the number of refugees that have arrived at its southern borders. At the same time, the burden on EU countries of large inflows of refugees has been unequally distributed, and ex-post re-allocation schemes to share this burden more equally have been impossible to implement. Moreover, many of those who arrived in European member states over the past decade have migrated for economic reasons rather than because of valid claims under the GCR. Hence, only a fraction is likely to attain some type of refugee status (see Figure 5), which adds the problem of deporting unsuccessful asylum applicants.

Despite the challenges to coordinate policies, there is a drastic need for a new regulatory framework agreeable to all member states that addresses the current and future challenges of refugee migration and replaces dated coordination attempts like the Dublin Convention with a more workable alternative. Such a framework should be based on two pillars: a coordinated policy that secures Europe's outer borders and deals with asylum claims before refugees have (illegally) crossed into mainland Europe, and an allocation mechanism that more equitably distributes the burden of refugee migrations across countries yet is flexible enough to account for national particularities and political circumstances.

On the first, a coordinated refugee policy should implement measures for deciding asylum claims at the outer borders of the EU before refugees enter the EU mainland. Such measures would need EU countries to agree in principle on exactly what constitutes a valid refugee claim. In practice, they would also require the establishment of facilities able to deal with large numbers of refugees

30 See e.g. Dustmann et al. (2016) for evidence. 
at the outskirts of the EU, and of EU courts that decide within weeks on claims according to agreed rules and interpretations of the GCR. On the second, once some form of refugee status has been granted, the refugee needs then to be allocated to a European country, possibly with the help of tradable refugee quotas, combined with ex-ante agreed allocation mechanisms that could take into account refugees' preferences, and seek to reduce the economic and political costs of refugee hosting. EU-level coordination that reduces the costs of refugee hosting could benefit all EU countries, not only those currently hosting the lion's share of asylum seekers. Such a system, if successfully implemented, would also deter potential migrants with no humanitarian reasons, and thereby reduce future flows, possibly quite radically.

Admittedly, establishing such a policy and its corresponding structures would be tremendously challenging. However, continued lack of ex-ante coordination and absence of agreed EU-wide rules when dealing with future challenges may be far more costly. The demographic developments in Africa and the Middle East, and the potential for conflict in these regions suggest that there will be similar challenges in the future. Canning et al. (2015), in a World Bank report, estimate that the population of Africa, Europe's southern neighbor, will increase to 2.8 billion over the next 45 years, from 1.11 billion in 2013. Similar projections are provided by a recent (2015) UN report on the World Population, ${ }^{31}$ which identifies Africa as the continent with the fastest growing populations over the next decades, while Europe's populations are shrinking. This, in combination with sluggish economic development, climate change, unstable political leadership, and possibly continued conflict, will lead to increased migration pressures on Europe. ${ }^{32}$ Among the 20 countries ranked highest according to the 2016 Fragile States Index by the Fund for Peace (used by the

\footnotetext{
${ }^{31} \mathrm{https}$ ://esa.un.org/unpd/wpp/Publications/Files/World_Population_2015_Wallchart.pdf

${ }^{32}$ Climate change induced phenomena such as desertification and scarcity of food is considered by some as possible future driver of large flows of "climate refugees", especially from the Sahel region of Africa (see http://time.com/4024210/climate-change-migrants/).
} 
OECD in their Report on States of Fragility), ${ }^{33} 17$ are located either in Africa (14) or in the Middle East (3), and often overlap with countries with the highest population growth. Europe's economic and political future will be severely affected on how it manages future movements instigated by conflict, persecution and deprivation. The current crisis is a wake-up call to develop the necessary institutions and implement needed coordination to be prepared for future challenges. ${ }^{34}$

The current crisis calls also for foreign policies that are more responsible. The recent and ongoing conflicts in the Middle East are a main reason for the humanitarian disaster and the ensuing refugee flows we have witnessed over the past years. Responsibility for interventions and policies that may have contributed to the current situation lies also with European countries. ${ }^{35}$ To prevent refugee movements in the future, European foreign policy should learn from past experiences, and be aimed at avoiding conflict and instability.

\section{References}

Adda J., Dustmann C. and Gorlach S., 2016. The Dynamics of Return Migration, Human Capital Accumulation, and Wage Assimilation. UCL, mimeo.

Aiyar, S., Barkbu, B., Batini, N., Berger, H., Detragiache, E., Dizioli, A., Ebeke, C., Lin, H., Kaltani, L., Sosa, S. and Spilimbergo, A., 2016. The Refugee Surge in Europe: Economic Challenges. IMF Discussion Note No.16/02. 
Bell B., Fasani F. and Machin S., 2013. Crime and Immigration: Evidence from Large Immigrant Waves. The Review of Economics and Statistics, 21(3) p.p. 1278-1290.

Ben-Porath, Y., 1967. The Production of Human Capital and the Life Cycle of Earnings. Journal of Political Economy, 75(4), p.p. 352-365.

Bevelander P. and Pendakur R., 2014. The Labor Market Integration of Refugee and Family Reunion Immigrants: A Comparison of Outcomes in Canada and Sweden. Journal of Ethnic and Migration Studies, 40(5), p.p 689-709.

Bratsberg B., Raaum O. and Røed K., 2014. Immigrants, Labour Market Performance and Social Insurance. Economic Journal, 124(580), p.p. F644-F683.

Bratsberg B., Raaum O. and Røed K., 2016. Labor Market Integration of Refugees in Norway. Mimeo Frisch Centre.

Canning, D., Raja, S. and Yazbeck, A.S. eds., 2015. Africa's Demographic Transition: Dividend Or Disaster?. World Bank Publications.

Cortes K. E., 2004. Are Refugees Different from Economic Immigrants? Some Empirical Evidence on the Heterogeneity of Immigrant Groups in the United States. The Review of Economics and Statistics, 86(2), p.p. 465-480.

Couttenier, M., Preotu, V., Rohner, D. and Thoenig, M., 2016. The Violent Legacy of Victimization: Post-Conflict Evidence on Asylum Seekers, Crimes and Public Policy in Switzerland. CEPR Discussion Papers 11079.

Damm A. P., 2009. Ethnic Enclaves and Immigrant Labor Market Outcomes: QuasiExperimental Evidence. Journal of Labor Economics, 27(2), p.p. 281-314.

Dustmann, C., 1993. Earnings Adjustment of Temporary Migrants. Journal of Population Economics, 6(2), p.p. 153-168.

Dustmann, C., 1999. Temporary Migration, Human Capital and Language Fluency of Migrants. Scandinavian Journal of Economics, 101(2), p.p. 297-314.

Dustmann, C., 2000. Temporary Migration and Economic Assimilation. Swedish Economic Policy Review, 7, p.p. 213-244. 
Dustmann, C., Vasiljeva, K. and Damm, A. P., 2016. Refugee Migration and Electoral Outcomes. CReAM DP 19/16.

Dustmann C. and Schönberg, U., 2012. What Makes Firm-Based Vocational Training Schemes Successful? The Role of Commitment. American Economic Journal - Applied, 4(2), p.p. 36-61.

Edin P., Fredriksson P. and Åslund O., 2003. Ethnic Enclaves and the Economic Success of Immigrants-Evidence from a Natural Experiment. The Quarterly Journal of Economics, 118(1), p.p. 329-357.

Facchini, G., Lorz, O. and Willmann, G. 2006. Asylum seekers in Europe: the warm glow of a hot potato. Journal of Population Economics, 19(2), p.p.411-430.

Fernández-Huertas Moraga, J. and Rapoport, H., 2015(a). Tradable Refugee-Admission Quotas and EU Asylum Policy. CESifo Economic Studies, 61(3-4), pp.638-672.

Fernández-Huertas Moraga, J. and Rapoport, H., 2015(b). Tradable Refugee-Admission Quotas (TRAQs), the Syrian Crisis and the New European Agenda on Migration. IZA Journal of European Labor Studies, 4(1).

Hainmueller, J., Hangartner, D. and Lawrence, D. 2016. When lives are put on hold: Lengthy asylum processes decrease employment among refugees. Science Advances, Vol. 2, no. 8, e1600432.

Hatton, T. J. 2004. Seeking asylum in Europe. Economic Policy, 38, p.p.5-62.

Hatton T., 2009. The Rise and Fall of Asylum: What Happened and Why?. Economic Journal, 119(535), p.p 183-213.

Hatton, T.J., 2015. Asylum Policy in the EU: the case for deeper integration. CESifo Economic Studies, 61(3-4), pp.605-637.

Hatton T., 2016. Refugees, Asylum Seekers and Policy in OECD Countries. American Economic Review Papers and Proceedings, 106 (5), p.p. 441-445. 
Hatton, T.J. and Williamson, J. G. 2006. Refugees, Asylum Seekers and Policy in Europe, in F. Foders and R.F. Langhammer (eds.) Labour Mobility and the World Economy, Kiel: Springer.

Hornung H., 2014. Immigration and the Diffusion of Technology: The Huguenot Diaspora in Prussia. American Economic Review, vol. 104(1), pp 84-122.

Luik M.A., Emilsson H. and Bevelander P., 2016. Explaining the Male Native-Immigrant Employment Gap in Sweden: The Role of Human Capital and Migrant Categories. IZA DP No. 9943.

Moser P., Voena A. and Waldinger F., 2014. German-Jewish Émigrés and U.S. Invention. American Economic Review, 104(10), p.p 3222-3255.

Rühl S., Lederer H. W., 2001. Migrationsbericht 2001 der Ausländerbeauftragten im Auftrag der Bundesregierung. Beauftragte der Bundesregierung für Ausländerfragen (ed.), Berlin.

Rühl S., Neske M. and Currle E., 2004. Migrationsbericht der Beauftragten der Bundesregierung für Migration, Flüchtlinge und Integration im Auftrag der Bundesregierung (Migrationsbericht 2003). Beauftragte der Bundesregierung für Migration, Flüchtlinge und Integration im Auftrag der Bundesregierung (ed.), Berlin.

UNHCR, 2000. The State of the World's Refugees, Fifty Year of Humanitarian Action. Oxford University Press, Chapter 9.

UNHCR, 2015. Statistical Yearbook 2014

UNHCR, 2015b. UNHCR Refugee Resettlement Trends 2015

Worbs S. and Bund E., 2016. Qualifikationsstruktur, Arbeitsmarktbeteiligung und Zukunftsorientierungen. BAMF-Kurzanalyse, German Ministry for Migration and Refugees (Bundesamt für Migration und Flüchtlinge). 


\section{Figures}

Figure 1: From displacement to refugee status

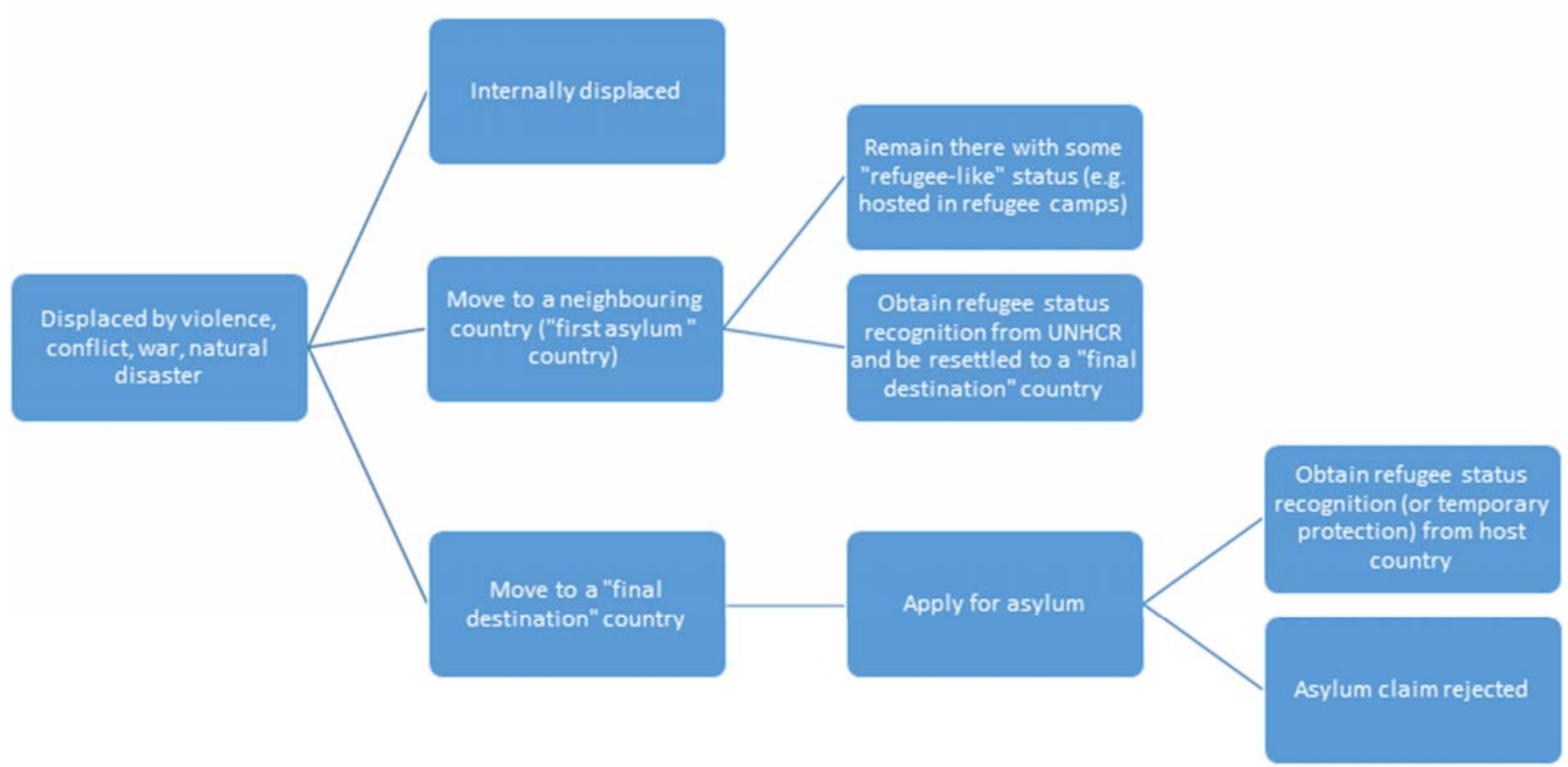


Figure 2: Evolution of refugee populations by origin continent (1980-2015)

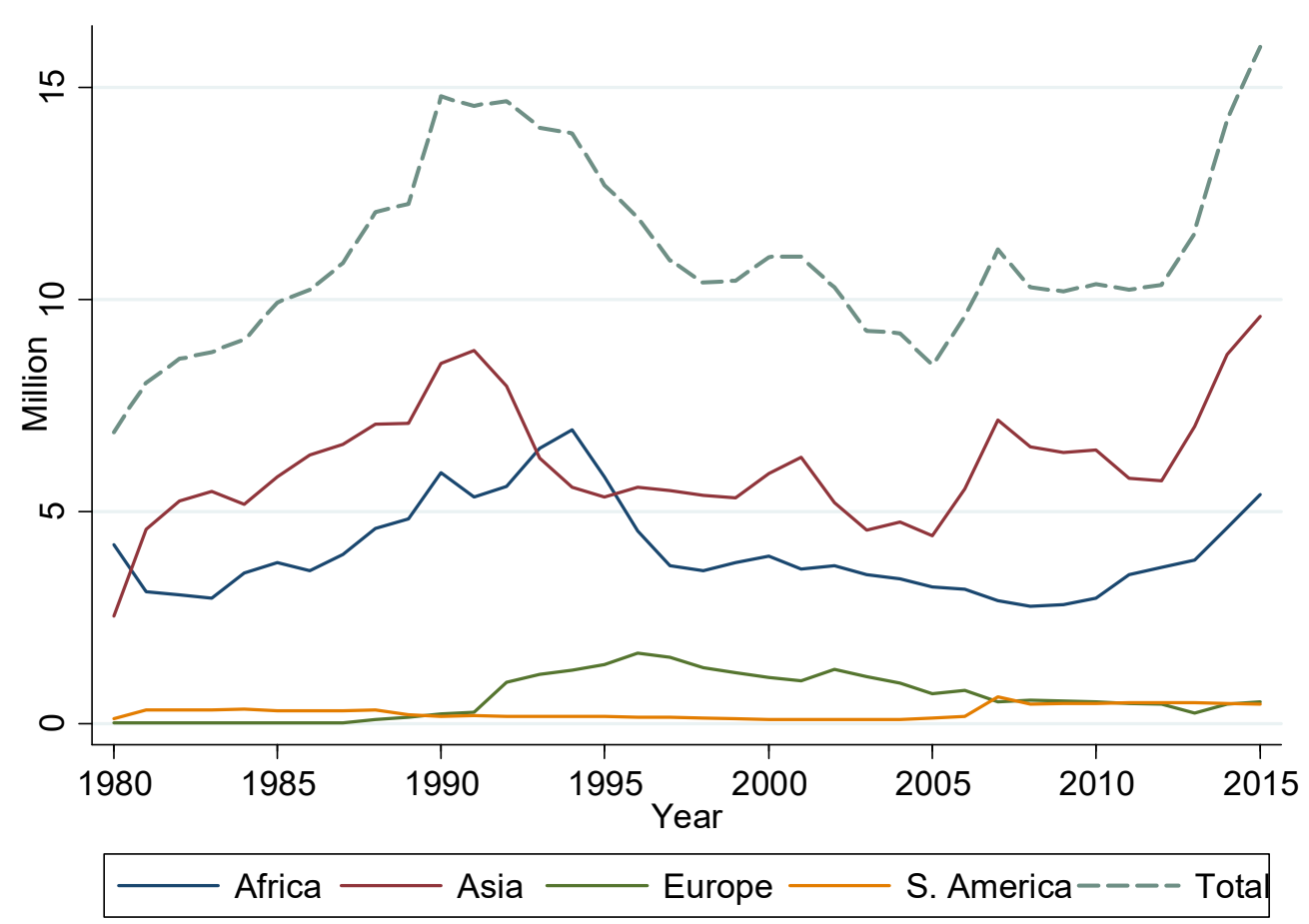

Note. The figure reports the evolution of the stock of refugees (in millions) by continent of origin, and overall, between 1980 and 2015. Source: Authors' calculations based on UNHCR data.

Figure 3 - Annual number of asylum applications by origin continent (2000-2015)

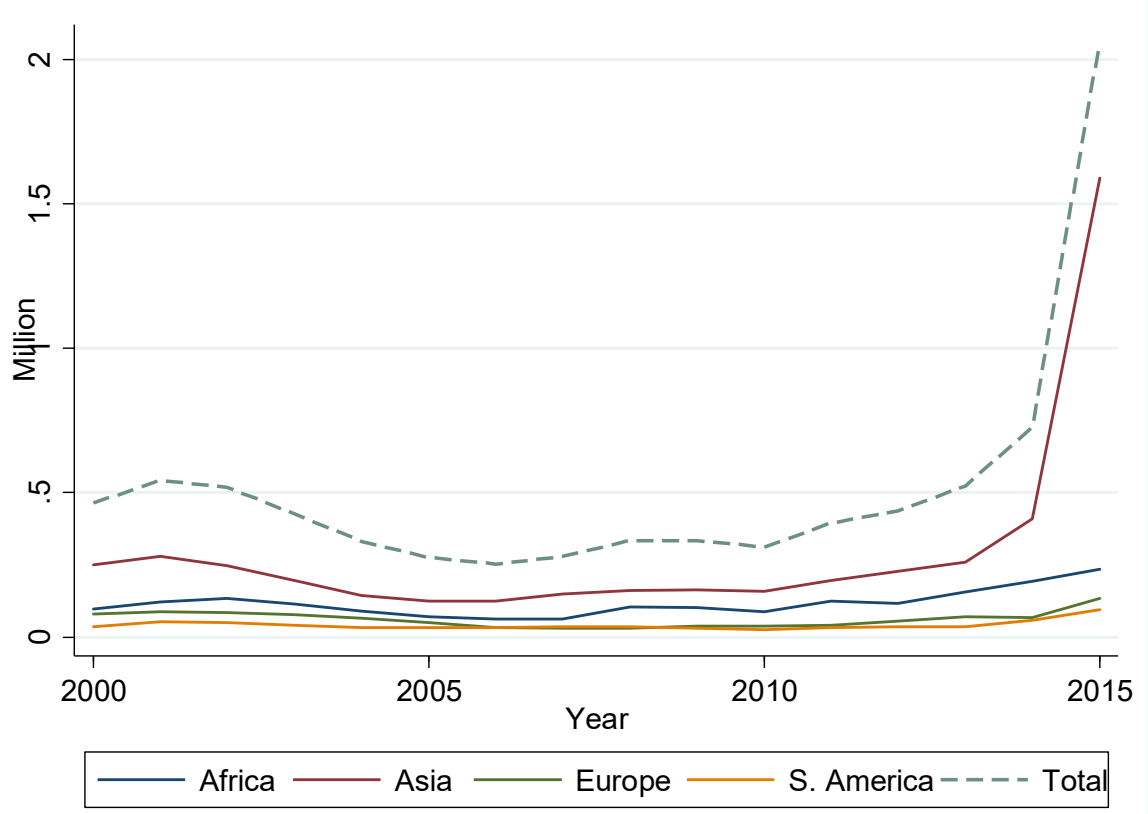

Note. The figure reports the annual number of asylum applications (in millions) by continent of origin, and overall, between 2000 and 2015. Source: Authors' calculations based on UNHCR data. 
Figure 4: Share of asylum applications cleared and applications received in EU15, Norway, and Switzerland (yearly averages for 2000-2014)

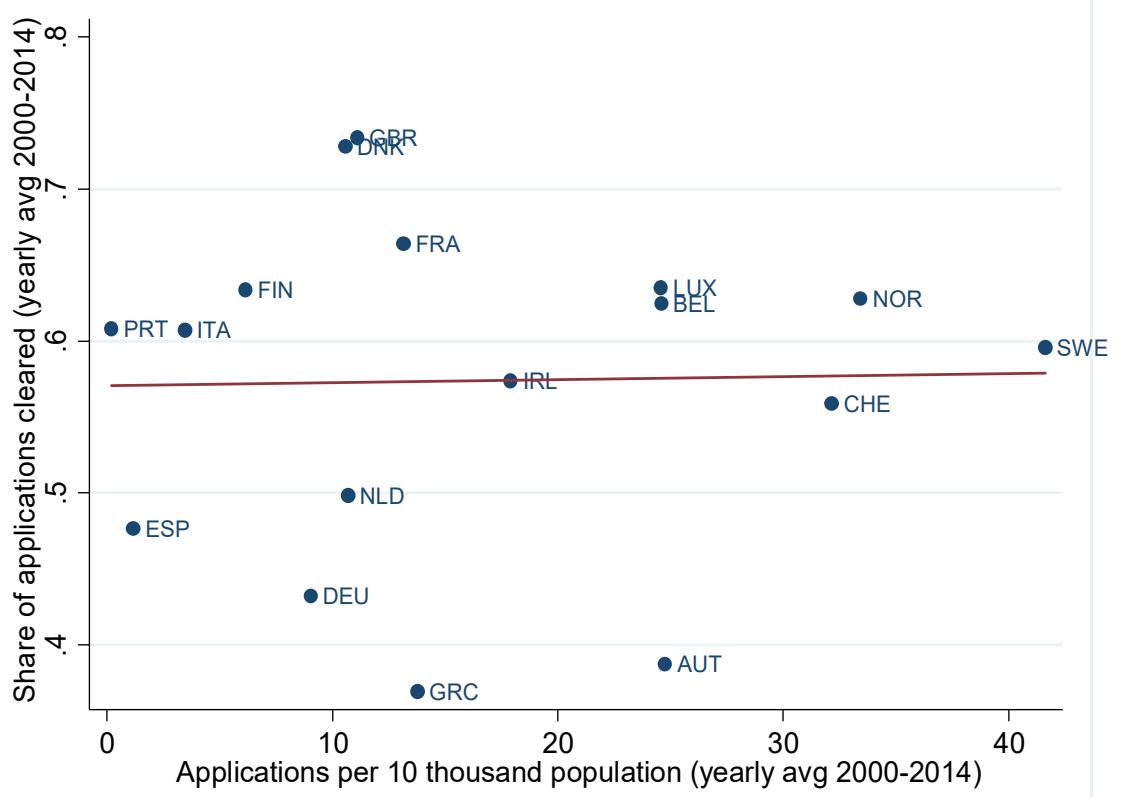

Note. The table plots the share of applications cleared against the applications received for EU15 countries, Norway and Switzerland. Numbers are yearly averages for the 2000 -2014 period. Source: Authors' calculations based on UNHCR data.

Figure 5: Refugee status recognition rates and share of asylum applications cleared in EU15, Norway, and Switzerland (yearly average for 2000-2014)

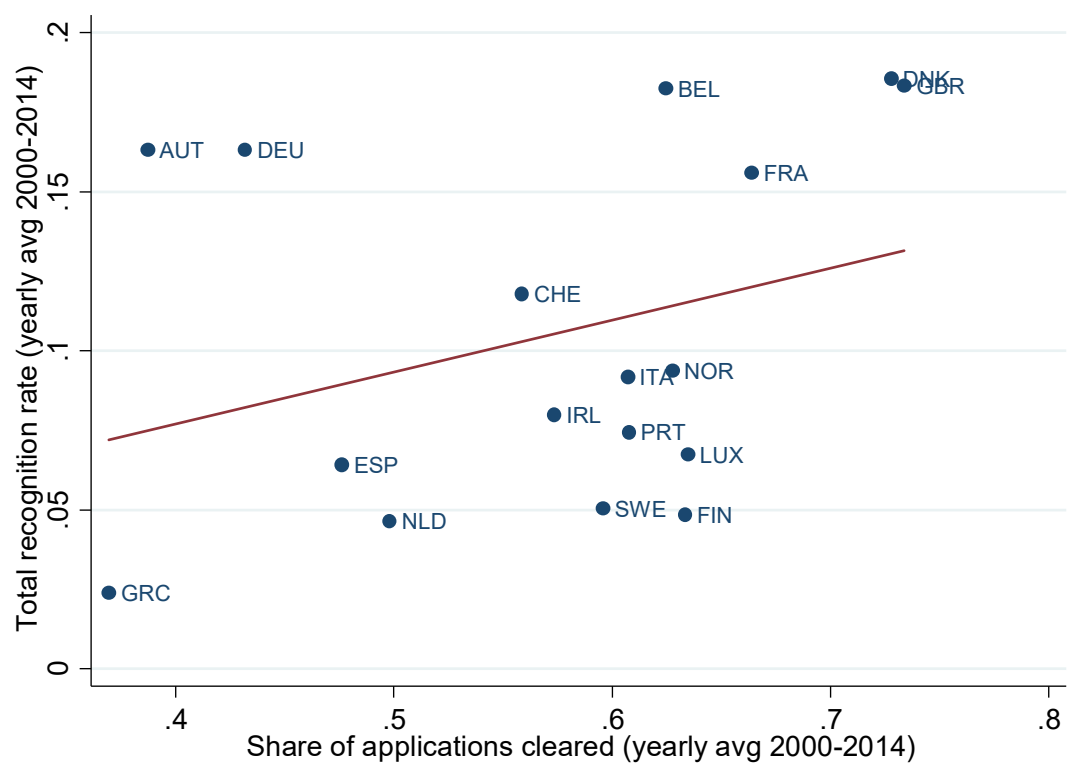

Note. The figure plots the total recognition rate against the share of applications cleared for EU15 countries, Norway and Switzerland. Numbers refer to yearly averages for the 2000-2014 period. Source: Authors' calculations based on UNHCR data. 
Figure 6: Illegal border crossings in Europe by route (2009-2015)

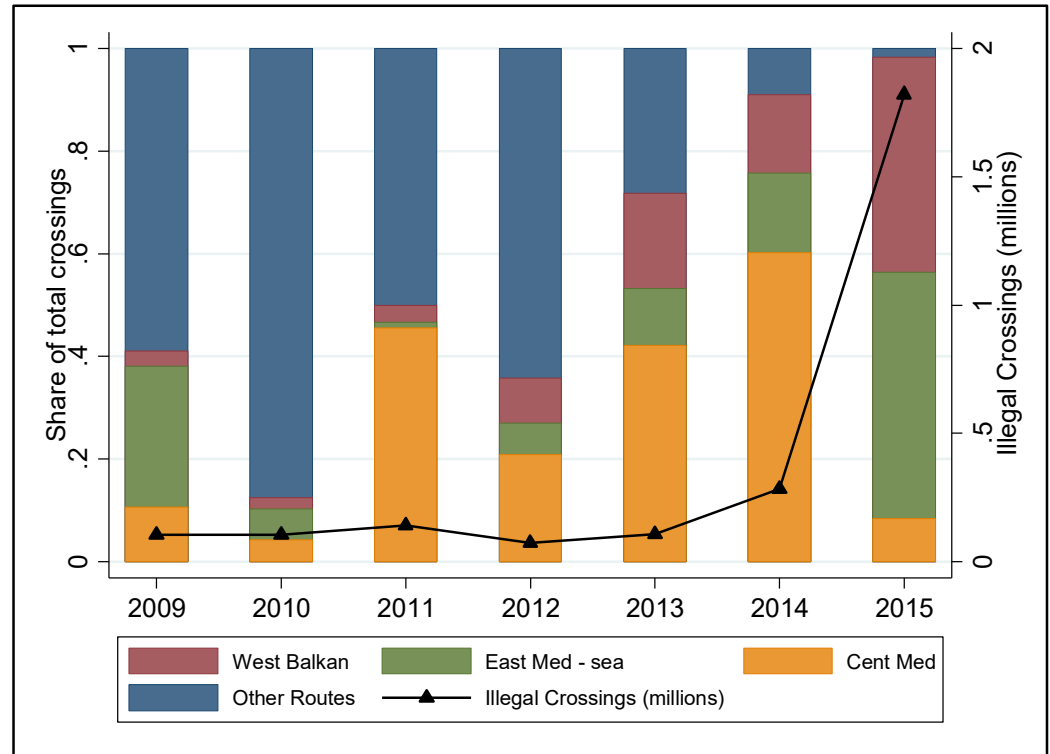

Note. The solid line and right axis represent the annual number of detected illegal border crossings (in millions) into the EU between 1980 and 2015; the vertical bars report the share of total crossings in each year detected on the Western Balkan route (red), Eastern Mediterranean sea route (green), Central Mediterranean route (yellow) and other routes (blue).

Source: Authors' calculations based on Frontex data.

Figure 7: Total asylum applications received between 2009 and 2015 and refugee population in 2009 by host country

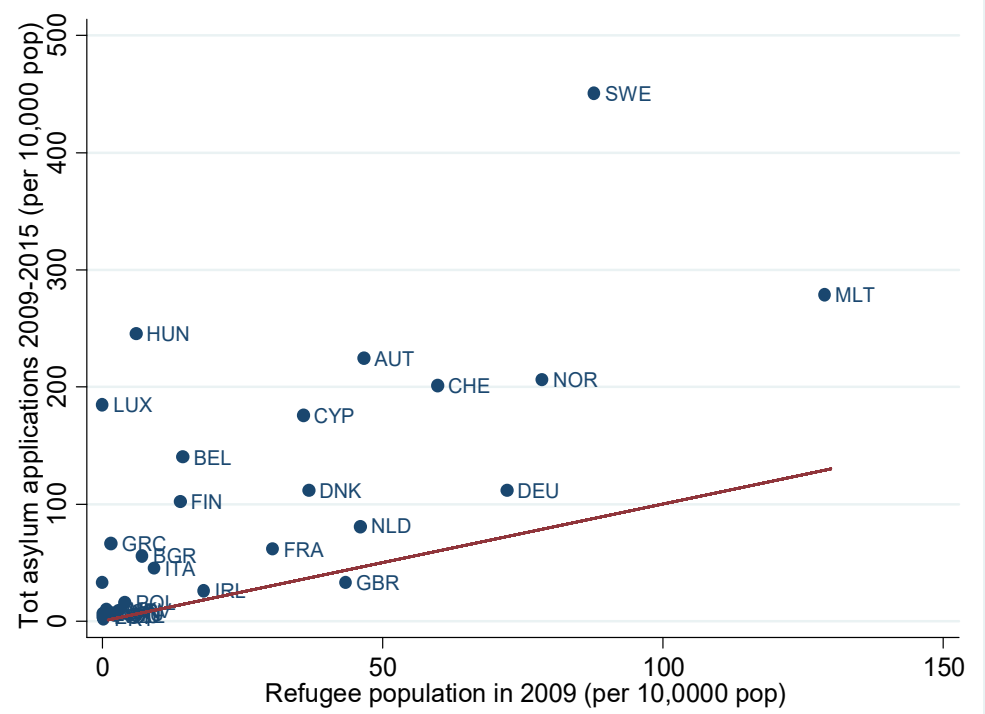

Note. The horizontal axis displays the 2009 stock of individuals with refugee status (full or subsidiary) per 10,000 population for all EU countries (plus Norway and Switzerland); the vertical axis shows the cumulated number of asylum applications between 2009 and 2015 per 10,000 population. The straight line is the equality line above which countries were receiving a higher number of applications than their 2009 refugee stock.

Source: Authors' calculations based on UNHCR data. 
Figure 8: Refugee-native and immigrant-native employment gaps

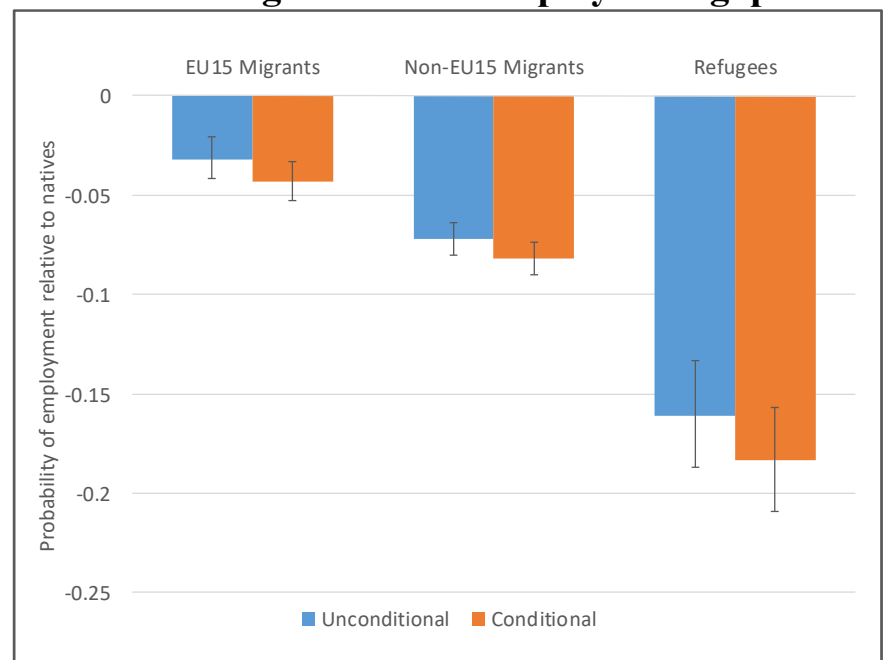

Note. The figure shows the unconditional and conditional differences in employment probabilities between EU15 and non-EU15 economic immigrants and natives, as well as between refugees and natives obtained using linear probability models. All regressions include host country fixed effects. Conditional employment gaps control for gender, age (dummy variables for 5-year age groups) and education (dummy variables for lower secondary and tertiary education). The sample includes all individuals aged between 25 and 64 not in full-time education or military service. We also report 90 percent confidence intervals based on robust standard errors.

Source: Authors' calculations based on EULFS 2008 data.

\section{Figure 9: Employment gaps by area of origin}

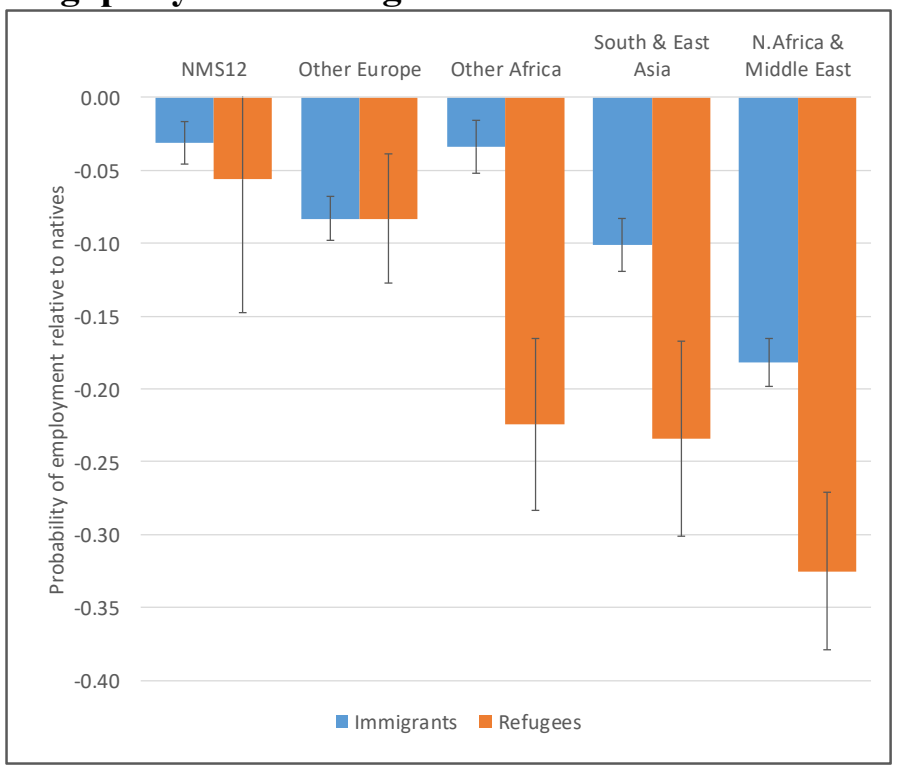

Note. The figure displays the differences in employment probabilities between economic immigrants and natives and between refugees and natives by area of origin obtained using linear probability models estimated separately for each origin area. The regressions control for gender, age (dummy variables for5-year age groups), education (dummy variables for lower secondary and tertiary education), and host country fixed effects. We also report 90 percent confidence intervals based on robust standard errors. The sample includes all individuals aged between 25 and 64 not in full-time education or military service but excludes economic immigrants from EU15 countries. NMS12 includes all countries that entered the EU in 2004 and 2007: Malta, Cyprus, Estonia, Latvia, Lithuania, Poland, the Czech Republic, Slovakia, Slovenia, Hungary, Bulgaria, and Romania.

Source: Authors' calculations based on EULFS 2008. 
Figure 10: Employment gaps by years since arrival

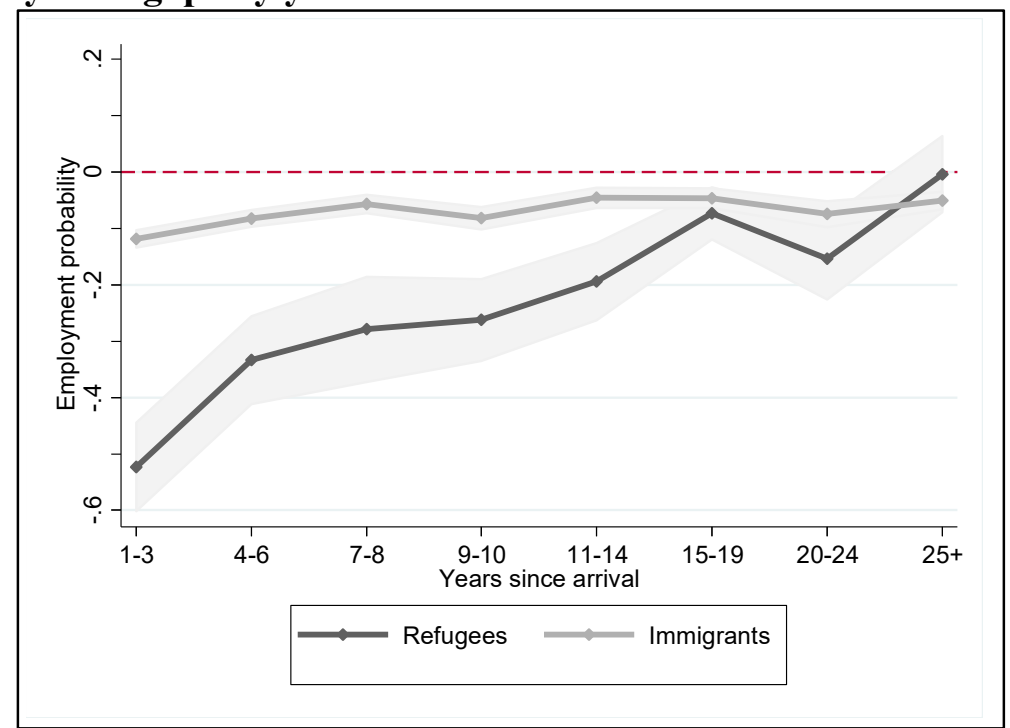

Note. The figure displays gaps (together with 90 percent confidence intervals) in the employment probabilities of economic immigrants versus natives and refugees versus natives by years since arrival obtained from linear probability models that condition on gender, age (dummy variables for 5-year age groups), education (dummy variables for lower secondary and tertiary education), and host country fixed effects. The sample includes individuals aged between 25 and 64 not in full-time education or military service.

Figure 11: Employment rate differentials by host country

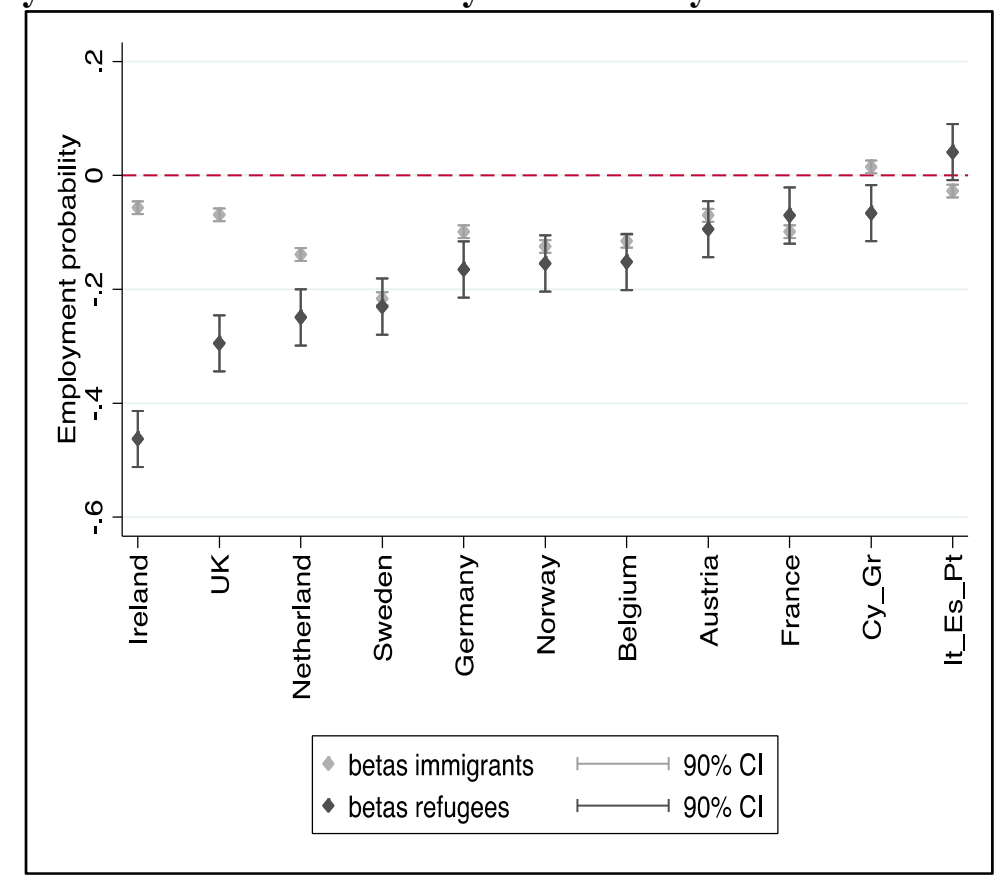

Note. The figure plots employment rate differentials (and 90 percent confidence intervals) between economic immigrants and natives as well as between refugee migrants and natives separately by host country, obtained from linear probability models estimated separately for each country that condition on gender, age (dummy variables for 5year age groups), education (dummy variables for lower secondary and tertiary education). Due to the low number of refugees in some countries, Italy, Spain and Portugal (It Es Pt) are grouped together, as are Cyprus and Greece (Cy_Gr). The sample includes all individuals aged between 25 and 64 not in full-time education or military service. 


\section{Tables}

Table 1: Origin and destination of UNHCR's population of concern (year 2015)

\begin{tabular}{lccccc}
\hline & \multicolumn{5}{c}{ Continent of origin } \\
& Africa & Asia & Europe & $\begin{array}{c}\text { South } \\
\text { America }\end{array}$ & World \\
\cline { 2 - 6 } & 19,124 & 29,423 & 2,672 & 7,765 & 58,991 \\
UNHCR population of concern (thous.) & 6,050 & 10,753 & 686 & 625 & 18,122 \\
Refugees (thous.) & 659 & 1,146 & 179 & 177 & 2,162 \\
\cline { 2 - 6 }$\quad$ of which are asylum seekers (thous.) & 0.316 & 0.365 & 0.257 & 0.080 & 0.307 \\
Share of refugees & & & & &
\end{tabular}

Refugees distribution across destinations

\begin{tabular}{rccccc} 
Africa & 0.819 & 0.026 & 0.000 & & 0.289 \\
Asia & 0.056 & 0.813 & 0.003 & 0.000 & 0.501 \\
Europe & 0.101 & 0.129 & 0.937 & 0.028 & 0.147 \\
North America & 0.019 & 0.025 & 0.057 & 0.430 & 0.039 \\
Oceania & 0.001 & 0.005 & 0.001 & 0.000 & 0.004 \\
South America & 0.003 & 0.001 & 0.001 & 0.541 & 0.020 \\
\cline { 2 - 6 } Total & 1 & 1 & 1 & 1 & 1
\end{tabular}

Note. The table reports, separately for each origin and for the world as a whole, the stock of the overall UNCHR population of concern (row 1), the stock of refugees (including asylum seekers, row 2) and the stock of asylum seekers (row 3). All figures are expressed in thousands. Row 4 reports the share of refugees (including asylum seekers) in the total UNHCR population of concern. The bottom rows report the distribution of refugees (including asylum seekers) from each origin continent across destination continents. 
Table 2: Different stages of becoming a refugee: The case of Syrians

\begin{tabular}{|c|c|c|c|c|c|}
\hline \multirow{2}{*}{\multicolumn{4}{|c|}{ Total population (pre-conflict) }} & \multirow{2}{*}{$\begin{array}{l}\text { Millions } \\
21.96\end{array}$} & \multirow[t]{2}{*}{$\%$} \\
\hline & & & & & \\
\hline Not displa & & & & 10.10 & 46.0 \\
\hline Displaced & & & & 11.86 & 54.0 \\
\hline \multirow[t]{15}{*}{ of which: } & \multicolumn{3}{|c|}{ Internally displaced } & 6.56 & 55.3 \\
\hline & \multicolumn{3}{|c|}{ Offered Resettlement (as of Apr 2016) } & 0.18 & 1.5 \\
\hline & \multicolumn{3}{|c|}{ Refugees/Asylumseekers at 31/12/2015: } & 5.12 & 43.2 \\
\hline & \multirow[t]{12}{*}{ of which: } & \multicolumn{2}{|c|}{ in Neighboring countries (as of 31/12/2015): } & 4.56 & 89.0 \\
\hline & & \multirow[t]{5}{*}{ of which: } & Turkey & 2.50 & 54.9 \\
\hline & & & Lebanon & 1.06 & 23.3 \\
\hline & & & Jordan & 0.63 & 13.8 \\
\hline & & & Iraq & 0.24 & 5.4 \\
\hline & & & Egypt & 0.12 & 2.6 \\
\hline & & \multicolumn{2}{|c|}{ in $\mathrm{EU} 28+\mathrm{NOR}+\mathrm{CH}$} & 0.49 & 9.6 \\
\hline & & \multirow[t]{5}{*}{ of which: } & Germany & 0.20 & 40.8 \\
\hline & & & Sweden & 0.10 & 20.8 \\
\hline & & & Austria & 0.03 & 6.8 \\
\hline & & & Netherlands & 0.03 & 6.5 \\
\hline & & & Hungary & 0.02 & 3.9 \\
\hline
\end{tabular}

Note. The table reports the total Syrian population, the number of internally displaced Syrians, the number of Syrian citizens offered Resettlement to a safe host country (the figure includes both confirmed pledges and individuals actually resettled) and those hosted in neighbouring countries and in the EU (including both asylum seekers and individuals with recognized refugee status). Source: Own calculations based on UNHCR Population Statistics data. 
Table 3: Total number of approved asylum applications and share with full Geneva refugee status by host country

\begin{tabular}{|c|c|c|c|c|c|c|}
\hline \multirow[b]{2}{*}{ Host Country } & \multicolumn{2}{|c|}{ All origin countries } & \multicolumn{2}{|c|}{ Syria } & \multicolumn{2}{|c|}{ Afghanistan } \\
\hline & $\begin{array}{l}\text { refugee } \\
\text { status } \\
\text { granted }\end{array}$ & $\begin{array}{c}\text { Share } \\
\text { with full } \\
\text { Geneva } \\
\text { status }\end{array}$ & $\begin{array}{c}\text { refugee } \\
\text { status } \\
\text { granted }\end{array}$ & $\begin{array}{c}\text { Share } \\
\text { with full } \\
\text { Geneva } \\
\text { status }\end{array}$ & $\begin{array}{l}\text { refugee } \\
\text { status } \\
\text { granted }\end{array}$ & $\begin{array}{c}\text { Share } \\
\text { with full } \\
\text { Geneva } \\
\text { status }\end{array}$ \\
\hline Austria & 11,351 & 0.769 & 3,653 & 0.913 & 1,534 & 0.576 \\
\hline Belgium & 8,479 & 0.810 & 1,705 & 0.740 & 1,269 & 0.638 \\
\hline Bulgaria & 7,000 & 0.737 & 6,406 & 0.753 & 24 & 0.292 \\
\hline Croatia & 26 & 0.615 & & & & \\
\hline Cyprus & 1,243 & 0.073 & 926 & 0.000 & & \\
\hline Czech Rep. & 376 & 0.218 & 71 & 0.000 & & \\
\hline Denmark & 5,670 & 0.689 & 4,002 & 0.782 & 128 & 0.188 \\
\hline Estonia & 20 & 1.000 & & & & \\
\hline Finland & 1,346 & 0.372 & 96 & 0.365 & 119 & 0.202 \\
\hline France & 21,093 & 0.789 & 1,468 & 0.640 & 712 & 0.431 \\
\hline Germany & 40,563 & 0.821 & 23,859 & 0.860 & 3,403 & 0.595 \\
\hline Greece & 3,852 & 0.539 & 718 & 0.735 & 827 & 0.440 \\
\hline Hungary & 476 & 0.504 & 171 & 0.643 & 75 & 0.227 \\
\hline Ireland & 504 & 1.000 & & & & \\
\hline Italy & 20,582 & 0.177 & 313 & 0.732 & 2,398 & 0.106 \\
\hline Latvia & 23 & 0.130 & & & & \\
\hline Lithuania & 91 & 0.264 & & & & \\
\hline Luxembourg & 197 & 0.802 & & & & \\
\hline Malta & 1,478 & 0.158 & 366 & 0.016 & & \\
\hline Netherlands & 13,250 & 0.207 & 5,439 & 0.064 & 415 & 0.439 \\
\hline Norway & 5,076 & 0.754 & 1,294 & 0.444 & 317 & 0.577 \\
\hline Poland & 450 & 0.593 & 132 & 0.871 & & \\
\hline Portugal & 109 & 0.165 & & & & \\
\hline Romania & 753 & 0.503 & 467 & 0.385 & 51 & 0.627 \\
\hline Slovakia & 113 & 0.124 & & & & \\
\hline Slovenia & 44 & 0.773 & & & & \\
\hline Spain & 1,583 & 0.241 & 1,162 & 0.105 & & \\
\hline Sweden & 32,347 & 0.331 & 16,404 & 0.107 & 1,765 & 0.405 \\
\hline Switzerland & 14,123 & 0.439 & 2,821 & 0.325 & 1,855 & 0.156 \\
\hline United Kingdom & 11,874 & 0.906 & 1,423 & 0.976 & 713 & 0.851 \\
\hline EU15 + NOR + CHE & 191,999 & 0.578 & 64,357 & 0.545 & 15,455 & 0.431 \\
\hline $\mathrm{EU} 28+\mathrm{NOR}+\mathrm{CHE}$ & 204,092 & 0.576 & 72,896 & 0.553 & 15,605 & 0.431 \\
\hline
\end{tabular}

Note. For each EU host country, the table reports the number of asylum applications approved and the share of applications granted full refugee status in 2014 according to the Geneva Convention for all origin countries and then separately for Syrians and Afghans. For countries whose application process has more than one level (e.g., first review, appeal), the numbers for all levels are summed. Source: 2014 UNHCR Statistical Year Book. 
Table 4: Examples of heterogeneity in asylum policies across European countries

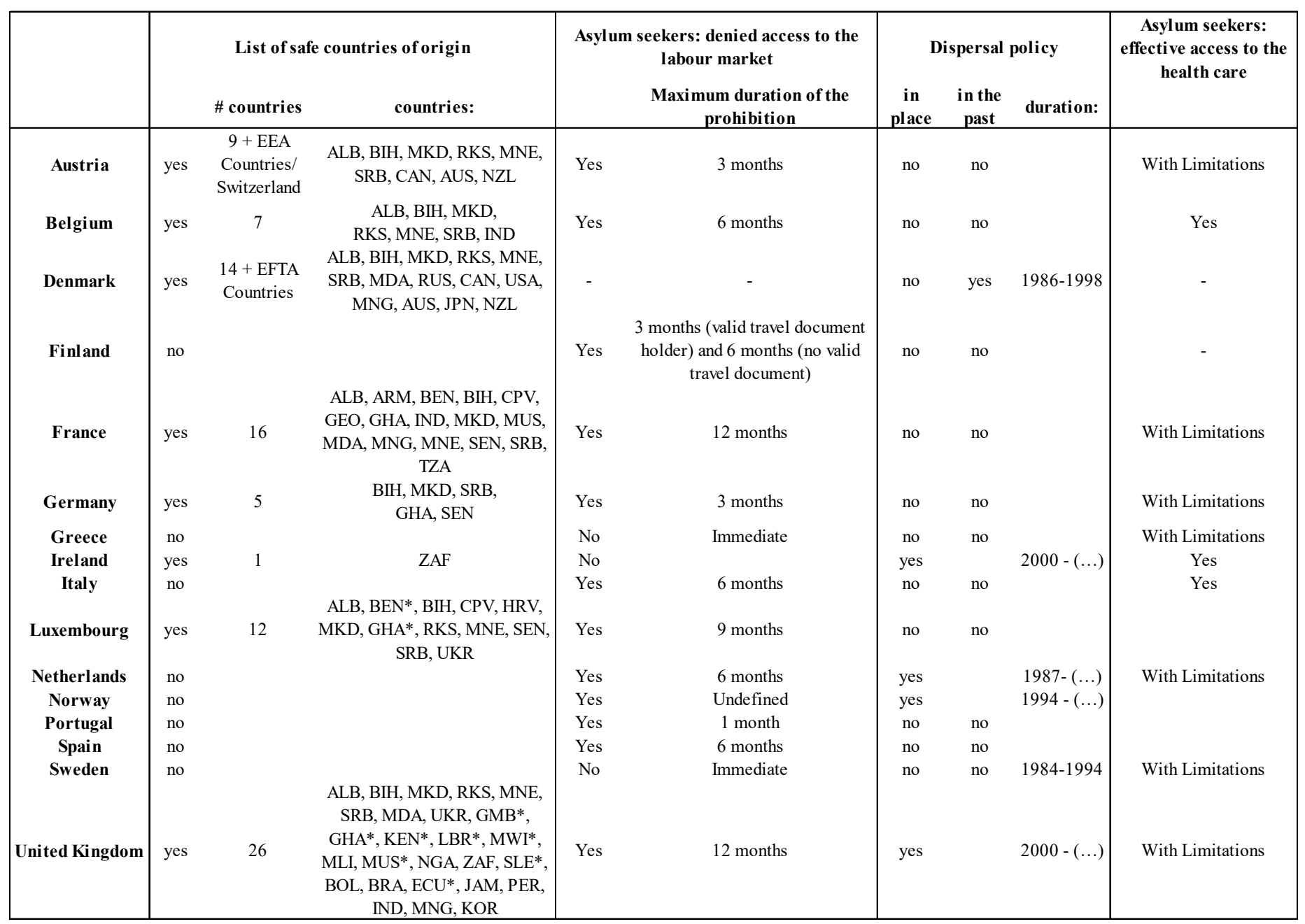

Note. The table reports selected aspects of the asylum policies of Western EU host countries. Column 1 reports the list of origin countries considered safe $(*=$ safe only for males); column 2 summarizes information on whether and for how long asylum seekers are denied access to the labour market while decisions on their applications are pending; column 3 documents whether and for how long a dispersal policy is or has been in place; and column 4 describes whether or not asylum seekers have effective access to health care. 
Table 5: Illegal border crossings and asylum applications in Europe, 2009-2015

Panel A: Illegal crossings to Europe, 2009-2015

\begin{tabular}{lccc} 
Origin & $\begin{array}{c}\text { Detected } \\
\text { attempts }\end{array}$ & $\begin{array}{c}\text { Share of } \\
\text { total } \\
\text { attempts }\end{array}$ & $\begin{array}{c}\text { Ratio } \\
2015 / 2009\end{array}$ \\
\hline Syria & 992,864 & $37.7 \%$ & 1,431 \\
Afghanistan & 529,595 & $20.1 \%$ & 29 \\
Iraq & 134,029 & $5.1 \%$ & 29 \\
Pakistan & 131,350 & $5.0 \%$ & 61 \\
Albania & 111,660 & $4.2 \%$ & 0.3 \\
Eritrea & 95,687 & $3.6 \%$ & 19 \\
Kosovo & 57,544 & $2.2 \%$ & 36 \\
Somalia & 54,451 & $2.1 \%$ & 2.1 \\
Nigeria & 48,491 & $1.8 \%$ & 14 \\
Bangladesh & 44,331 & $1.7 \%$ & 48 \\
\hline Total & $2,633,896$ & & 17 \\
\hline
\end{tabular}

Panel B: Asylum applications in Europe, 2009-2015

\begin{tabular}{lccc}
\multicolumn{1}{c}{ Origin } & Applications & $\begin{array}{c}\text { Share of } \\
\text { total } \\
\text { abolications }\end{array}$ & $\begin{array}{c}\text { Ratio } \\
2015 / 2009\end{array}$ \\
\hline Syria & 595,869 & $16.9 \%$ & 77.33 \\
Afghanistan & 360,542 & $10.2 \%$ & 8.10 \\
Serbia and Kosovo & 271,235 & $7.7 \%$ & 4.57 \\
Iraq & 214,471 & $6.1 \%$ & 6.51 \\
Eritrea & 151,754 & $4.3 \%$ & 4.95 \\
Russian Federation & 145,634 & $4.1 \%$ & 0.94 \\
Pakistan & 143,284 & $4.1 \%$ & 4.77 \\
Somalia & 126,815 & $3.6 \%$ & 1.00 \\
Nigeria & 108,889 & $3.1 \%$ & 2.51 \\
Albania & 107,817 & $3.1 \%$ & 32.91 \\
\hline Total & $3,522,378$ & & 4.74 \\
\hline
\end{tabular}

Note. Panel A reports, for Europe as a whole, the number of detected illegal crossings of European borders between 2009 and 2015 separately for each of the 10 main origin countries, the share of nationals from each origin country among total illegal crossings and the ratio of detected crossings in 2015 to detected crossings in 2009. Panel B reports separately for each of the 10 main origin countries the number of asylum applications filed in Europe (EU $28+\mathrm{NOR}+\mathrm{CH}$ ) between 2009 and 2015 and the share of nationals from each origin country among total asylum applications and the ratio of applications in 2015 to applications in 2009.

Sources: Panel A: Author elaboration of Frontex data. Panel B: Authors' calculations based on UNHCR data. 
Table 6: Total asylum applications in Europe between 2009 and 2015 by host country

\begin{tabular}{|c|c|c|}
\hline \multirow{2}{*}{ Host Country } & \multicolumn{2}{|c|}{ Tot Asylum Application 2009-2015 } \\
\hline & thousands & per 10,000 pop \\
\hline Germany & 902.7 & 110.1 \\
\hline Sweden & 413.6 & 446.9 \\
\hline France & 389.5 & 60.5 \\
\hline Italy & 256.7 & 43.5 \\
\hline Hungary & 244.5 & 243.8 \\
\hline United Kingdom & 204.1 & 32.9 \\
\hline Austria & 186.9 & 224.2 \\
\hline Switzerland & 151.7 & 196.9 \\
\hline Belgium & 147.2 & 136.9 \\
\hline Netherlands & 127.4 & 77.3 \\
\hline Norway & 98.7 & 205.7 \\
\hline Greece & 73.1 & 65.8 \\
\hline Denmark & 61.2 & 111.1 \\
\hline Poland & 60.9 & 16.0 \\
\hline Finland & 53.6 & 100.7 \\
\hline Bulgaria & 41.3 & 55.3 \\
\hline Spain & 34.2 & 7.4 \\
\hline Cyprus & 14.0 & 175.5 \\
\hline Ireland & 11.7 & 25.8 \\
\hline Malta & 11.3 & 274.7 \\
\hline Romania & 9.6 & 4.7 \\
\hline Luxembourg & 9.1 & 184.7 \\
\hline Czech Republic & 4.8 & 4.6 \\
\hline Croatia & 3.8 & 8.7 \\
\hline Slovak Republic & 2.8 & 5.3 \\
\hline Lithuania & 2.3 & 7.1 \\
\hline Portugal & 2.2 & 2.1 \\
\hline Slovenia & 1.5 & 7.5 \\
\hline Latvia & 1.4 & 6.4 \\
\hline Estonia & 0.5 & 3.7 \\
\hline EU15 + NOR + CHE & 3123.7 & 76.5 \\
\hline EU28 + NOR + CHE & 3522.4 & 68.5 \\
\hline
\end{tabular}

Note. The table reports for each EU host country (plus Norway and Switzerland) the total number and the number per 10,000 population of asylum applications received between 2009 and 2015 (in thousands).

Source: Authors' calculations based on UNHCR data. 
Table 7: Refugees and asylum seekers as a share of the population, 2014 Panel A: Middle Eastern Countries

\begin{tabular}{|c|c|c|c|}
\hline & Refugees & $\begin{array}{c}\text { Country } \\
\text { population }\end{array}$ & $\begin{array}{c}\text { Refugees per } \\
10.000 \text { population }\end{array}$ \\
\hline Lebanon & $1,161,439$ & $4,546,774$ & 2,554 \\
\hline Jordan & 672,862 & $6,607,000$ & 1,018 \\
\hline Turkey & $1,693,686$ & $76,667,864$ & 221 \\
\hline Iraq & 279,585 & $34,812,326$ & 80 \\
\hline
\end{tabular}

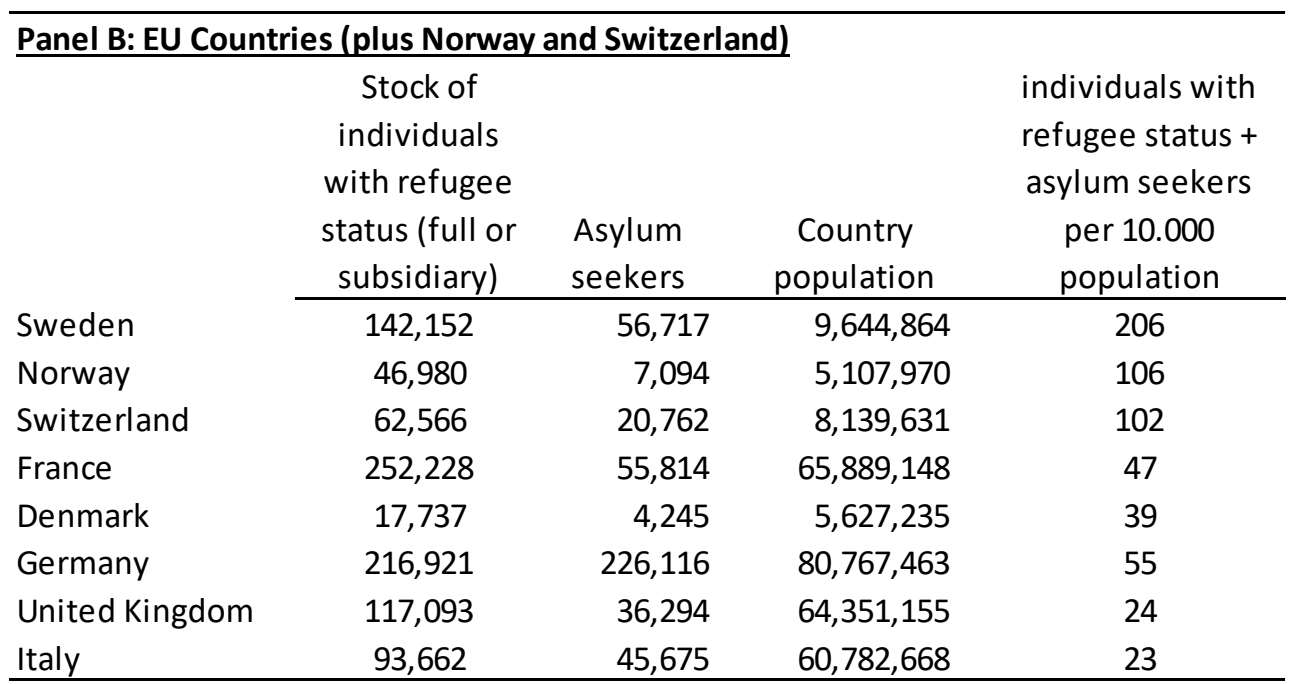

Note. Panel A reports the total number of refugees, the country's population, and the number of refugees per 10.000 population in selected Middle Eastern countries in 2014. Panel B displays the total number of individuals with full GCR or subsidiary refugee status, the total number of asylum applications, the country's population, and the number of individuals with refugee status plus asylum seekers per 10,000 population in selected European countries in 2014. Source: Authors' calculations based on UNHCR data.

Table 8: Basic characteristics of refugee population (EUFLS 2008)

\begin{tabular}{rcccc}
\hline & Refugees & $\begin{array}{c}\text { Immigrants } \\
\text { non-EU15 }\end{array}$ & $\begin{array}{c}\text { Immigrants } \\
\text { EU15 }\end{array}$ & Natives \\
\hline Share of males & 0.61 & 0.47 & 0.47 & 0.50 \\
Mean age & 43.9 & 41.2 & 42.6 & 44.7 \\
Share with Lower-secondary education & 0.38 & 0.44 & 0.27 & 0.32 \\
Share with Tertiary education & 0.23 & 0.22 & 0.28 & 0.26 \\
\cline { 2 - 5 } Number of observations & 2,554 & & 33370 & \\
\end{tabular}

Note. The table compares socio-economic characteristics of refugee migrants (who entered the country because of international protection), economic migrants from EU15 and non-EU15 countries, and natives. The sample includes all individuals aged between 25 and 64, not in education or military service. Source: EULFS 2008. 
Table 9 - Refugee-Immigrant (non-EU15) employment gap

\begin{tabular}{lcccc}
\hline \hline & Baseline & $\begin{array}{c}\text { Conditional } \\
\text { on years } \\
\text { since arrival } \\
\end{array}$ & $\begin{array}{c}\text { Conditional } \\
\text { on area of } \\
\text { origin } \\
(\mathbf{1})\end{array}$ & $\begin{array}{c}\text { Conditional } \\
\text { on both }\end{array}$ \\
& $(\mathbf{2})$ & $\mathbf{( 3 )}$ & $\mathbf{( 4 )}$ \\
\hline Refugee-Immigrant gap & $-0.109 * * *$ & $-0.121^{* * *}$ & $-0.083^{* * *}$ & $-0.095^{* * *}$ \\
& $(0.017)$ & $(0.017)$ & $(0.017)$ & $(0.016)$ \\
\hline Years since arrival FE & & $\mathrm{X}$ & & $\mathrm{X}$ \\
Area of origin FE & & & $\mathrm{X}$ & $\mathrm{X}$ \\
Observations & 468,404 & 468,404 & 468,404 & 468,404 \\
R-squared & 0.216 & 0.216 & 0.217 & 0.218 \\
\hline \hline
\end{tabular}

Note. We regress the usual employment indicator on an indicator for refugee, a foreign-born one (which equals 1 for both immigrants and refugees, and 0 for natives) as well as the usual individual characteristics (age dummies, gender, education dummies) and country of residence fixed effects. We then, from column 2 onward include the refugee indicator and a full set of interactions between the foreign-born indicator and years since arrival ones (column 2), between the foreign-born indicator and area of origin ones (column 3), and between the foreign-born indicator and both years and area of origin ones (column 4). With such a specification the coefficient on refugee (reported in the table) delivers the mean difference between employment probability of refugees and non-EU15 immigrants within each value of year since arrival (in column 2) and within each area of origin (in column 3) or within both (in column 4). Sample: individuals aged between 25 and 64, not in education or military service. Immigrants from EU15 or North America are excluded. Robust standard errors in brackets. $* * * \mathrm{p}<0.01, * * \mathrm{p}<0.05,{ }^{*} \mathrm{p}<0.1$

Table 10: Educational attainment and employment probabilities of recent refugees in Germany

\begin{tabular}{|c|c|c|c|c|c|c|c|c|}
\hline & \multicolumn{4}{|c|}{$\underline{\text { school attendance }}$} & \multicolumn{4}{|c|}{ labor market participation } \\
\hline & \multirow[b]{2}{*}{ none } & \multirow{2}{*}{$\begin{array}{l}\text { up to } 9 \\
\text { years }\end{array}$} & \multirow{2}{*}{$\begin{array}{l}10-14 \\
\text { years }\end{array}$} & \multirow{2}{*}{$\begin{array}{c}\text { at least } 15 \\
\text { years }\end{array}$} & \multicolumn{4}{|c|}{ looking for out of the } \\
\hline & & & & & employed & work & labor force & in training \\
\hline Afghanistan & 18.3 & 27.8 & 48.9 & 2.8 & 29.1 & 20.7 & 19.9 & 16.3 \\
\hline Iraq & 25.9 & 41.4 & 25.7 & 3.5 & 38.9 & 21.5 & 26 & 6 \\
\hline Syria & 16.1 & 35.5 & 41.5 & 4.3 & 24.7 & 26.4 & 27.8 & 6.9 \\
\hline $\mathrm{N}$ & \multicolumn{4}{|c|}{2,403} & \multicolumn{4}{|c|}{2,805} \\
\hline
\end{tabular}

Note. The table summarizes the results of 2014 German Ministry for Immigration and Refugees survey, which focused on individuals who obtained official refugee status and initially applied for asylum in Germany between 2007 and 2012. 


\section{Data Appendix}

\section{A.1 Asylum applications and refugee status recognitions}

The annual information on UNHCR's population of concern and asylum application processing are taken from the UNHCR Statistical Online Population Database, which classifies persons of concern as follows: (a) refugees, individuals recognized under the 1951 Convention relating to the Status of Refugees, its 1967 Protocol, and/or the 1969 OAU Convention Governing the Specific Aspects of Refugee Problems in Africa; individuals recognised in accordance with the UNHCR Statute; individuals granted complementary forms of protection or enjoying temporary protection; and, since 2007, individuals in a refugee-like situation; (b) asylum seekers, individuals who have sought international protection and whose claims for refugee status have not yet been determined; (c) returned refugees, former refugees who have returned to their country of origin but are yet to be fully integrated; (d) internally displaced persons (IDPs), individuals who have been forced to leave their homes or places of habitual residence as a result of, or in order to avoid the effects of, armed conflict, and who have not crossed an international border; (e) returned IDPs, IDPs who were beneficiaries of UNHCR's protection and assistance activities and who returned to their areas of origin or habitual residence during the year; (f) stateless persons; (g) other individuals of concern, those who do not fall directly into any of the previous groups but to whom UNHCR extends its protection and/or assistance services. The data on asylum application processing include the numbers of applications submitted, pending applications at the beginning and end of the year, applications recognized, applications rejected, and applications otherwise closed. Data are reported bilaterally for all world countries. As of the time of writing, the data, which are available on line, had been updated to December 31, 2014. 
UNHCR also provides a monthly data set of asylum applications lodged in 38 European and 6 non-European countries between 1999 and 2015. Where possible, our figures exclude repeat/reopened asylum applications and applications lodged on appeal or with courts.

\section{A.2 Illegal crossings}

Quarterly data on illegal entries by route and origin country for each quarter from Q1 2009 to Q4 2015 were obtained from Frontex, the European Agency for the Management of Operational Cooperation at the External Borders of the Member States of the European Union, which began gathering such information in 2009. Frontex defines illegal crossings as "the number of thirdcountry nationals detected by Member State authorities when entering or attempting to enter illegally the territory between border crossing points at external borders". The recorded number of illegal crossings may differ from the actual flows of undocumented immigrants for at least two reasons: First, not all illegal crossings are detected, meaning that detected crossings are a lower bound for actual unauthorized crossings. Illegal crossings are determined by the combination of the number of people who attempt an illegal entry and the level of enforcement. Any variation in the number of detected crossings, therefore, can be due to variations both in the underlying flow of people and in the border enforcement intensity. This complicates comparisons over time and across routes of recorded crossings. A second issue is that multiple entry attempts by the same migrant are re-counted, leading to an over-estimation of the number of individuals attempting to cross the border illegally. Nonetheless, in the absence of reliable information on the size of these two effects, detected illegal crossings are the best available proxy for undocumented migratory pressure. 
The data set distinguishes between the following nine routes: the Central Mediterranean route, the circular route from Albania to Greece, the eastern border route, the Eastern Mediterranean routes (sea and land), the West African route, the Western Mediterranean routes (sea and land), and the Western Balkan route.

\section{A.3 Labour market outcomes of refugee and economic migrants}

Our analysis is based on the 2008 wave of the European Labour Force Survey (EULFS), which is conducted in the 27 Member States of the European Union and two countries of the European Free Trade Association (EFTA). It is a large quarterly household sample survey of people aged 15 and over, as well as of persons outside the labour force. The National Statistical Institute of each member country is responsible for selecting the sample, preparing the questionnaires, conducting the direct interviews among households, and forwarding the results to Eurostat in accordance with the common coding scheme.

In certain countries, the 2008 survey included an ad-hoc module that asked for information on reason for migration, thereby allowing us to identify refugees versus other (economic) migrants. We therefore focus our analysis on the countries in which this ad-hoc module was administered: Austria, Belgium, Cyprus, Germany, Spain, France, Greece, Ireland, Italy, Netherland, Norway, Portugal, Sweden, and the UK. The reason-for-migration question was asked to all non-native individuals who arrived in the country of residence when they were over 16 years of age ${ }^{36}$. The 2008 interviewees were asked to choose among 8 options: (1) employment, intra-corporate transfer; (2) employment, job found before migrating; (3) employment, no job found before migrating; (4) study; (5) international protection; (6) accompanying family/family reunification;

\footnotetext{
${ }^{36}$ Non-native individuals (immigrants and refugees) are defined as "foreign born" in all countries except Germany where they are defined as "foreign nationals".
} 
(7) family formation, and (8) other. We assign the label refugee to all those who selected option 5, international protection, and the label economic migrant to all those choosing any of the other reasons. The sample for our empirical analysis includes individuals of working age (between 25 and 64 years old), not in full-time education or military service. After dropping all observations with missing data on education, reason for migration, or area of origin, we have an estimation sample of 476,518 individuals, of whom 440,594 are natives, 33,370 are economic immigrants, and 2,554 are refugees. 


\section{Appendix Tables}

Table A1: Refugee-native and immigrant-native employment rate differentials

\begin{tabular}{lcccccc}
\hline \hline & $\mathbf{( 1 )}$ & $\mathbf{( 2 )}$ & $\mathbf{( 3 )}$ & $\mathbf{( 4 )}$ & $\mathbf{( 5 )}$ & $\mathbf{( 6 )}$ \\
\hline Immigrant & $-0.059^{* * *}$ & $-0.085^{* * *}$ & $-0.070^{* * *}$ & & & \\
& $(0.004)$ & $(0.004)$ & $(0.004)$ & & & \\
Refugee & $-0.161^{* * *}$ & $-0.216^{* * *}$ & $-0.183^{* * *}$ & $-0.161^{* * *}$ & $-0.215^{* * *}$ & $-0.183^{* * *}$ \\
& $(0.017)$ & $(0.017)$ & $(0.016)$ & $(0.017)$ & $(0.017)$ & $(0.016)$ \\
Immigrant_EU15 & & & & $-0.032^{* * *}$ & $-0.041^{* * *}$ & $-0.043^{* * *}$ \\
& & & & $(0.007)$ & $(0.006)$ & $(0.006)$ \\
Immigrant_nonEU15 & & & & $-0.072^{* * *}$ & $-0.105^{* * *}$ & $-0.082^{* * *}$ \\
& & & & $(0.005)$ & $(0.005)$ & $(0.005)$ \\
\hline Gender and age & & $\mathrm{X}$ & $\mathrm{X}$ & & $\mathrm{X}$ & $\mathrm{X}$ \\
Education & & & $\mathrm{X}$ & & & $\mathrm{X}$ \\
Observations & 476,518 & 476,518 & 476,518 & 476,518 & 476,518 & 476,518 \\
R-squared & 0.02 & 0.18 & 0.22 & 0.02 & 0.18 & 0.22 \\
\hline \hline
\end{tabular}

Note. The table reports differences in employment probabilities between economic immigrants/refugees relative to natives (columns 1-3) and between EU15/non-EU15 immigrants/refugees relative to natives (columns 4-6) estimated using linear probability models. The mean of the outcome variable is equal to 0.73 . The sample includes all individuals aged between 25 and 64, not in full-time education or military service. All regressions control for gender (dummy for male), age (dummies for 5 -year age groups), education (dummies for lower secondary and tertiary education), and host country fixed effects. Robust standard errors are in parentheses. ${ }^{* * *} \mathrm{p}<0.01,{ }^{* *} \mathrm{p}<0.05,{ }^{*} \mathrm{p}<0.1$.

Table A2: Employment rate differentials by origin area

\begin{tabular}{lccccc}
\hline \hline & NMS12 & $\begin{array}{c}\text { Other } \\
\text { Europe }\end{array}$ & $\begin{array}{c}\text { Other } \\
\text { Africa }\end{array}$ & $\begin{array}{c}\text { South \& } \\
\text { East Asia }\end{array}$ & $\begin{array}{c}\text { N.Africa \& } \\
\text { Middle } \\
\text { East }\end{array}$ \\
& $\mathbf{( 1 )}$ & $\mathbf{( 2 )}$ & $\mathbf{( 3 )}$ & $\mathbf{( 4 )}$ & $\mathbf{( 5 )}$ \\
\hline Immigrant & $-0.031^{* * *}$ & $-0.083^{* * *}$ & $-0.034^{* * *}$ & $-0.101^{* * *}$ & $-0.182^{* * *}$ \\
& $(0.009)$ & $(0.009)$ & $(0.011)$ & $(0.011)$ & $(0.010)$ \\
Refugee & -0.056 & $-0.083^{* * *}$ & $-0.224^{* * *}$ & $-0.234^{* * *}$ & $-0.325^{* * *}$ \\
& $(0.056)$ & $(0.027)$ & $(0.036)$ & $(0.041)$ & $(0.033)$ \\
\hline Observations & 445,719 & 447,643 & 443,300 & 444,664 & 445,365 \\
R-squared & 0.23 & 0.23 & 0.23 & 0.23 & 0.23 \\
F-test (Imm. Vs Ref.) & 0.21 & 0.00 & 25.03 & 9.96 & 17.45 \\
Prob>F & 0.65 & 0.99 & 0.00 & 0.00 & 0.00 \\
\hline \hline
\end{tabular}

Note. The table reports differences in employment probabilities between economic immigrants/refugees and natives estimated separately (using linear probability models) for different origin areas. The sample includes all individuals aged between 25 and 64, not in full-time education or military service. Economic immigrants from EU15 countries are excluded. All regressions control for gender, age (dummy variables for 5-year age groups), education (dummy variables for lower secondary and tertiary education), and host country fixed effects. We also report tests for the equality of coefficients for economic immigrants versus refugees. Robust standard errors are in parentheses. $* * *$ $\mathrm{p}<0.01, * * \mathrm{p}<0.05, * \mathrm{p}<0.1$. 
Table A3: Robustness of results to country exclusion

\begin{tabular}{|c|c|c|c|c|c|c|c|c|c|c|c|c|c|}
\hline Excluded country(s): & $\begin{array}{c}\text { None (full } \\
\text { sample) }\end{array}$ & Austria & Belgium & $\begin{array}{c}\text { Cyprus } \\
\text { and } \\
\text { Greece } \\
\text { (4) }\end{array}$ & Germany & $\begin{array}{c}\text { Italy, } \\
\text { Portugal } \\
\text { and } \\
\text { Spain } \\
(6)\end{array}$ & France & Ireland & Netherland & Norway & (11) & (12) & $\begin{array}{l}\text { Ireland } \\
\text { and UK } \\
\text { (13) }\end{array}$ \\
\hline Immigrant & $\begin{array}{c}-0.070^{* * *} \\
(0.004)\end{array}$ & $\begin{array}{c}-0.070^{* * *} \\
(0.004)\end{array}$ & $\begin{array}{c}-0.068 * * * \\
(0.004)\end{array}$ & $\begin{array}{c}-0.072 * * * \\
(0.004)\end{array}$ & $\begin{array}{c}-0.062^{* * *} \\
(0.004)\end{array}$ & $\begin{array}{c}-0.093^{* * *} \\
(0.005)\end{array}$ & $\begin{array}{c}-0.064^{* * *} \\
(0.004)\end{array}$ & $\begin{array}{c}-0.070 * * * \\
(0.004)\end{array}$ & $\begin{array}{c}-0.067 * * * \\
(0.004)\end{array}$ & $\begin{array}{c}-0.070^{* * *} \\
(0.004)\end{array}$ & $\begin{array}{c}* 0.068^{* * *} \\
(0.004)\end{array}$ & $\begin{array}{c}-0.070 * * * \\
(0.004)\end{array}$ & $\begin{array}{c}-0.071^{* * *} \\
(0.004)\end{array}$ \\
\hline Refugee & $\begin{array}{c}-0.183^{* * *} \\
(0.016) \\
\end{array}$ & $\begin{array}{c}-0.190 * * * \\
(0.017) \\
\end{array}$ & $\begin{array}{c}-0.185^{* * *} \\
(0.017) \\
\end{array}$ & $\begin{array}{c}-0.186^{* * *} \\
(0.017) \\
\end{array}$ & $\begin{array}{c}-0.192^{* * *} \\
(0.014) \\
\end{array}$ & $\begin{array}{c}-0.187^{* * *} \\
(0.016) \\
\end{array}$ & $\begin{array}{c}-0.189^{* * *} \\
(0.017) \\
\end{array}$ & $\begin{array}{c}-0.182^{* * *} \\
(0.016)\end{array}$ & $\begin{array}{c}-0.179 * * * \\
(0.017) \\
\end{array}$ & $\begin{array}{c}-0.184^{* * *} \\
(0.017) \\
\end{array}$ & $\begin{array}{c}-0.179 * * * \\
(0.018) \\
\end{array}$ & $\begin{array}{c}-0.164^{* * *} \\
(0.018) \\
\end{array}$ & $\begin{array}{c}-0.162^{* * *} \\
(0.019) \\
\end{array}$ \\
\hline Observations & 476,518 & 457,615 & 463,019 & 433,135 & 456,195 & 315,485 & 447,543 & 440,967 & 418,316 & 462,995 & 441,590 & 428,320 & 392,769 \\
\hline R-squared & 0.22 & 0.21 & 0.21 & 0.22 & 0.22 & 0.22 & 0.21 & 0.22 & 0.21 & 0.21 & 0.22 & 0.23 & 0.23 \\
\hline F-test (Imm. vs Ref.) & 46.35 & 46.56 & 46.24 & 44.04 & 82.61 & 29.78 & 52.26 & 44.55 & 39.50 & 45.70 & 37.90 & 24.66 & 23.31 \\
\hline Prob $>F$ & 0.00 & 0.00 & 0.00 & 0.00 & 0.00 & 0.00 & 0.00 & 0.00 & 0.00 & 0.00 & 0.00 & 0.00 & 0.00 \\
\hline
\end{tabular}

Note. The table tests the robustness of employment probability estimates to the exclusion of single (or group of) countries. Column (1) estimates the regression on the full sample of countries, reproducing column (3) of Table A1. From column (2) onward, countries are excluded, one at a time, from the sample. In column (13) both the UK and Ireland are dropped at the same time. All regressions control for gender (dummy for male), age (dummies for 5-year age groups), education (dummies for lower secondary and tertiary education), and host country fixed effects. Robust standard errors are in parentheses. $* * * \mathrm{p}<0.01, * * \mathrm{p}<0.05, * \mathrm{p}<0.1$. 